\title{
On the Rate of Growth of some Sea Fishes, and the Age and Size at which they begin to Breed.
}

\author{
By
}

\section{J. T. Cunningham, M.A.}

The following paper is to be regarded as the sequel of that published in the preceding number of this Journal, on the rate of growth and distribution of young marine fishes. I am still continuing inquiries of this character, and have now to record the additional results obtained up to the end of March, 1892. I have also described and criticised some of the results of other workers in the same field.

\section{Gadus morrhua, the Cod.}

Continuous observations on the growth of marine fishes in captivity have very seldom been made up to the present time. Isolated observations are scattered here and there in Day's British Fishes, and Marion, in the Annales du Musée de Marseille of 1891, has described how he reared the alevins of a species of mullet and of Sargus till they were nearly a year old, but none of these experiments were carried on with the object or with the result of ascertaining definitely the most important facts in the life-history of the species. So far as I have discovered, continuous observations on the growth of fish from the earliest stage almost to the adult condition have only once been attempted before I carried out my own upon flounders, namely, those of Dannevig upon cod. Dannevig's results are described in his Reports upon the Fish Hatchery of Flödevig, published by the Selskab for de Norske Fiskeriers Fremme, * and an account of them by Professor Cossar Ewart is to be found in the Fifth Report of the Fishery Board for Scotland for the year 1886. In one respect Dannevig's experiment was superior

* See Aarsberetning, 1886, of Selskabet for de Norske Fiskeriers Fremme, Bergen; Beretning om Flödevigens Udklækningsanstalts Virksomhed i Femaaret, 1883-1888, Arendal, 1889. 
to mine, namely, that he hatched his specimens as well as reared them, while mine were obtained at an early stage of life from the sea. I believe that this is the only case in which larvæ artificially hatched from marine pelagic fish eggs have been successfully reared in captivity. This success can only be attributed to the fact that the young fry were turned into a large reservoir of clean sea water. The reservoir was made by building two dams across a narrow rocky gully, opening on to the shores of the inlet on which Flödevig stands. Flödevig is about 6 miles from the town of Arendal on the south coast of Norway. The reservoir was about 43 yards long, 20 yards broad, and 5 yards in greatest depth, and sea water could be constantly pumped into it by means of a steamengine. The reservoir was like an enclosed portion of the seashore, and seaweeds grew in it as on the shore.

Into this large reservoir Dannevig put, on the 3rd May, 1886, about 500,000 cod larvæ hatched on the 27th April. The larvæ when put in were $5 \mathrm{~mm}$. or $\frac{1}{5}$ of an inch in length. Up to the 6 th of June their growth was slow, they measured then only $15 \mathrm{~mm}$., and up to this time they refused the artificial food, namely, finely chopped mussels and fish, which was offered to them. After this they began to eat the food thrown into the pond, and their rate of growth rapidly increased. On July 12th, when two and a half months old, they measured $5.5 \mathrm{~cm}$. or nearly $2 \cdot 2$ inches. The subsequent growth will be seen from the following table:

\begin{tabular}{|c|c|c|c|c|c|}
\hline \multicolumn{2}{|c|}{ Date. } & \multicolumn{2}{|r|}{ Age. } & & Length. \\
\hline 1886 & May 3 & $\cdots$ & 6 days & $\cdots$ & $5 \mathrm{~mm}$. \\
\hline & June 6 & $\ldots$ & 1 month 9 days & $\ldots$ & $1.5 \mathrm{~cm}$. \\
\hline & July 12 & $\ldots$ & 2 months 15 days & $\cdots$ & $5.5 \mathrm{~cm}$. \\
\hline & Aug. 12 & $\ldots$ & 3 months 15 days & $\ldots$ & $7 \cdot 0 \mathrm{~cm}$. \\
\hline & Sept. 12 & $\ldots$ & 4 months 15 days & $\ldots$ & $8.5 \mathrm{~cm}$. \\
\hline & Oct. 12 & $\ldots$ & 5 months 15 days & $\ldots$ & 11.5 to $15.7 \mathrm{~cm}$. \\
\hline 1888 & Feb. & $\cdots$ & 1 year 10 months & $\cdots$ & $35 \cdot 6$ to $40 \cdot 7 \mathrm{~cm} ., 14$ to 16 inches. \\
\hline & Autumn & $\ldots$ & $2 \frac{1}{2}$ years & $\ldots$ & 9 to 18 inches. \\
\hline
\end{tabular}

The last entry in the above list is taken from a separate report by Dannevig on the work done at Flödevig between 1883 and 1888 . This report is dated February, 1889, but the paragraph concerning the cod was apparently written in the autumn of 1888 . It is there stated that the total number of fish surviving was from 200 to 400 , and that they seemed likely to spawn in the following spring. I have not been able to find anything further about these fish in later reports.

Fulton finds the smallest ripe cod to be 20 inches long, and Holt thinks that the smallest ripe female is considerably larger. Dannevig's specimens had not reached 20 inches in two and a half 
years, and there is no evidence in his experiment that any specimens spawned at two years of age. In fact, his experiment was made merely with the object of proving that artificially hatched larvæ could grow into adult fish, and he seems to have paid little attention to questions as to the size or age at which sexual maturity is attained. It seems to me probable that, either by reason of the confinement or of insufficient food, the size reached by Dannevig's specimens in two a half years was considerably below the normal size of free individuals of that age.

Dannevig mentions in his Report for 1886 that on the 13th May he placed 5000 newly hatched flounders in the pond or reservoir above mentioned with the young cod; in the translation given by Prof. Ewart, loc. cit., the species is erroneously given as Pleuronectes limanda, but Dannevig himself states that skrubbe, the word he uses, means $\mathrm{Pl}$. flesus. In May, 1888, these flounders had attained a length of 7 or 8 inches, so that some of my captive flounders, described in the following section, though reared in comparatively small tanks, were larger than those kept by Dannevig in a large open-air reservoir. Dannevig says nothing about the spawning of these captive flounders.

Ewart states that Dannevig reared herring in the same reservoir, but I can find no reference to herring in the reports of the latter.

\section{Pleuronectes flesus, the Flounder.}

The specimens of this species reared in the aquarium, whose length in the spring of last year was given in my previous paper, were measured again this year when they were about two years old. Their lengths and conditions were as follows:

February 23rd, 1892. Specimens in a table tank 5 feet by $2 \frac{1}{2}$ feet in area, by 1 foot 5 inches deep, measured and examined. Total number of specimens 24 .

Of these three were ripe males, and one was a female, which though not actually ripe had a well-developed ovary, which would without doubt yield ripe ova this season. The lengths of these were-

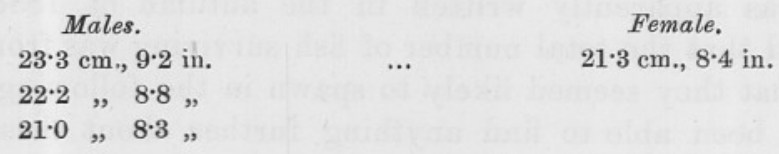

The remaining specimens were all unripe; their sexes were not determined. Their lengths were- 

(1) $24 \cdot 8 \mathrm{~cm} ., 9 \cdot 7 \mathrm{in.}$
(8) $17 \cdot 3 \mathrm{~cm}$.
(15) $14 \cdot 0 \mathrm{~cm}$.
(2) 20.8,
(9) $17 \cdot 2$,
(16) $13 \cdot 7$,
(3) $20 \cdot 0$,
(10) $16 \cdot 7$,
(17) 13.4,
(4) $19 \cdot 7$,
(11) $16 \cdot 4$,
(5) $19 \cdot 2$,
(12) $15 \cdot 7$,
(18) $12 \cdot 5$,
(6) 18.0,
(13) 14.5,
(7) $18 \cdot 0$,
(14) $14 \cdot 2$,
(19) $12 \cdot 2$,
(20) $10.5,4 \cdot 1 \mathrm{in}$.

I separated the three ripe males and the ripening female, placing them in another tank, and returned the rest alive to the tank they were taken from.

On March 21st I examined the unripe specimens again, to see if any had become ripe in the interval, but could find no signs of sexual maturity in any of them. Two of them had died in consequence of the handling they underwent on the first occasion. I now took one specimen, the third on the above list, killed it and dissected it. I found it was a female; the ovary was quite small, and showed no signs of reproductive activity. The organ extended only about $1.5 \mathrm{~cm}$. beyond the posterior boundary of the abdominal cavity, and the ova were not separately visible to the eye. It seemed evident that this specimen would not have spawned during the present season.

The other specimens of the same age had been living in a large tank 18 feet by $3 \frac{1}{2}$ feet in area, and 2 feet in depth. I emptied this tank on February 24th, and found in it sixty-five flounders. Of these nine were males in a perfectly ripe condition, whose lengths were-
(1) $23 \cdot 4 \mathrm{~cm}, 9 \cdot 2 \mathrm{in}$.
(4) $21 \cdot 0 \mathrm{~cm} ., 8 \cdot 3 \mathrm{in}$.
(7) $19 \cdot 8 \mathrm{~cm}, 7 \cdot 8 \mathrm{in}$.
(2) $23 \cdot 1,9 \cdot 1$,
(5) $20 \cdot 8,8 \cdot 2$,
(8) $17 \cdot 4,6 \cdot 9$,
(3) $22 \cdot 1,8 \cdot 7$,
(6) $20 \cdot 0,7 \cdot 9$,
(9) $16 \cdot 2,6 \cdot 4$,

Three were females with large swollen ovaries, not perfectly ripe, but evidently preparing to spawn this season; their lengths were-
(1) $26.7 \mathrm{~cm} ., 10.5 \mathrm{in}$.
(2) $24 \cdot 8 \mathrm{~cm} ., 9 \cdot 8 \mathrm{in.}$
(3) $23 \cdot 0 \mathrm{~cm} ., 9 \cdot 0 \mathrm{in}$.

The rest were unripe; they varied in length from $23 \cdot 2 \mathrm{~cm}$. or $9 \cdot 15$ inches down to $7 \cdot 2 \mathrm{~cm}$. or $2 \cdot 8$ inches.

I placed the ripe males and ripening females in a separate tank, and returned the unripe specimens to the tank they came from.

On March 24th I emptied the tank and examined the unripe specimens again. I found one more ripe male, but this was apparently one that had escaped capture on the previous occasion, as it was injured by the net. It was $21 \cdot 3 \mathrm{~cm}$. long.

Among the specimens in the small tank, two were left-sided or reversed, that is, having the eyes on the left side instead of on the right. Of the sixty-six specimens in the large tank four were 
reversed; one of these sixty-six had a few small patches of pigment on the lower side of the skin, but in no other specimen did any pigment occur on the lower side.

Thus the largest of these specimens known to be two years of age was $26.7 \mathrm{~cm}$. long or 10.5 inches, while the smallest was $7 \cdot 2 \mathrm{~cm}$. or $2 \cdot 8$ inches. I feel convinced myself that this great difference in size is chiefly due to differences in nutrition, produced by the competition for a limited supply of food among a large number of individuals in a confined space. It proves at least that under certain conditions a flounder may be only 3 inches long when two years old, and it is quite possible that these conditions are sometimesrealised in nature. On the other hand, the size of the larger specimens agrees perfectly with the size of those taken at sea which I had estimated to be of about this age.

With respect to sexual or reproductive maturity, the spawning season is not yet passed, and some of the specimens now unripe may be found to be ripe in April or even in May. But I am inclined to think that the majority, if not all, of the specimens found to be unripe in February and March will not spawn this year. I was surprised to find the proportion of ripe specimens so small. It was 16 per cent. in the small tank, 20 per cent. in the large, or 19 per cent. taking the two together. In my last paper I recorded the fact that none of these captive flounders were ripe at one year of age, and inferred that they would breed for the first time when two years old. It now appears that only a small proportion breed at that age, the majority not attaining to sexual maturity in the second spawning season after that in which they were hatched. It seems probable, therefore, that the greater number of young flounders breed for the first time when three years old, while a small proportion begin to breed at two years. If this were the case normally in flounders and other flat-fishes, not only under artificial but under natural conditions, then in this respect the life-history of the flat-fish would resemble that of the salmon, which has been so long and so attentively studied. For, according to the account given by Day in his British Fishes, it has been conclusively proved that out of the salmon fry hatched in a given spring, which become parrs in the following summer, a certain small proportion become smolts in the following spring when one year old, and descend to the sea, while the larger number remain in the rivers as parrs until they are two years old, and then migrate as smolts. Now a smolt which descends in spring returns as a grilse the following autumn and spawns. Therefore a proportion of salmon breed for the first time two years after the autumn in which they themselves were spawned, while the majority do not become sexually mature until the third autumn. 
Of course it may be objected that it is unsafe to draw inferences from what takes place under artificial conditions; that fish kept in captivity in tanks may grow at a different rate and breed at different ages from those in their natural state. But the degree to which such differences occur may be ascertained with sufficient certainty by comparing observations made on specimens taken at sea with those made on captive specimens. In my last paper I showed that specimens living under natural conditions are taken at the spawning season, which must be one year old, and yet which are considerably smaller than the smallest ripe specimen recorded. Thus there is here some evidence that the development of the reproductive organs is not greatly modified by confinement.

Dr. Fulton's investigation of the question of immature fish was of a statistical character, and his criterion of immaturity for each species was a criterion of length. He ascertained the length of the smallest ripe fish among a very large number examined and measured, and he regarded all specimens smaller than this as sexually immature, all larger specimens as mature. Mr. Holt in the course of his observations on the west coast of Ireland introduced a new and important consideration, namely, the distinction of the sexes. Dr. Fulton spoke merely of a ripe specimen without reference to the question whether it was male or female, but it had long been known, e.g. in the case of the salmon, that a male fish may be sexually ripe when very small indeed, while the smallest ripe female is a great deal larger. Mr. Holt, therefore, records the sex as well as the size of ripe specimens, and finds the smallest ripe female to be considerably larger than the smallest ripe male. The importance of this distinction had been also present to my own mind long before Mr. Holt's results were published. In fact, in my previous paper, which appeared in November, 1891, I have in all cases given the sex of the smallest ripe specimen observed, and in the case of the dab have given the length of the smallest ripe specimen of each sex. 'My knowledge of Mr. Holt's observations is derived from a proof copy of his reports in the Report of the Council of the Royal Dublin Society for 1891.

In the statistical inquiries of both Holt and Fulton, it is tacitly assumed that the sexual maturity of a fish of a given species depends only on its size. The smallest ripe specimen is found, and it is assumed that all specimens above this size are to be considered as mature. The method of these inquiries naturally involved such an assumption, for while the minimum size of ripe or ripening specimens was ascertained, no attempt was made in them to ascertain the maximum size of immature specimens. In fact, when a specimen caught at sea is not ripe or ripening, we have at present no 
criterion by which to find out whether it has spawned before or not; it may be sexually immature, or it may have spawned previously, its sexual organs being merely in an inactive state at that particular time of the year.

Now it was, $\dot{a}$ priori, improbable that the sexual maturity of a fish should depend simply on its size. This could only be the case if every specimen grew to exactly the same size in the same time, if there were no individual variation in the rate of growth. That such a variation exists is obvious from the examination of fishes taken at sea, and my observations on flounders, \&c., in captivity, have shown how great the variation may be. Thus, when Fulton finds the smallest ripe flounder to be 7 inches long, it by no means follows that all specimens larger than this have begun to breed. I have given above the lengths of the twelve of my captive specimens which were found to be ripe males in February and March this year. The smallest of them is $6 \cdot 4$ inches long, the largest $9 \cdot 2$ inches. Therefore even a male flounder may be more than 9 inches long before it begins to breed-before it spawns for the first time. Eight out of the twelve ripe males are over 8 inches long. If these had been taken at sea last November, they would have been over 7 inches long, and would, according to Fulton's method, have been classed as mature, while, as a matter of fact, they had not begun to breed, had never yet produced milt. Similarly, with the females there are only four ripe among my captive specimens, and their lengths are from 8.4 inches to 10.5 inches, so that a female flounder may be more than 10 inches long before it breeds for the first time.

The results thus obtained for the flounder probably apply more or less exactly to other kinds of flat-fishes. Hence we may conclude that, when the smallest size of the mature female in a given species has been ascertained, many females do not reach maturity until they are somewhat larger than this. Therefore, in order to exclude all immature individuals, a limit of size must be taken which is above the minimum size of mature females.

\section{Pleuronectes limanda, the Dab.}

In the autumn of last year I collected from Cawsand Bay, and other parts of Plymouth Sound, a number of small dabs which I judged to be derived from the spawning of the spring of the same year.

The dates of collection and lengths of these were as follows: 


\begin{tabular}{|c|c|c|c|c|c|}
\hline 891 Sept. 29 & $\ldots$ & \multicolumn{2}{|c|}{ 4 specimens } & $\ldots$ & $4 \cdot 2-5 \cdot 3 \mathrm{~cm}$ \\
\hline Oct. 1 & $\ldots$ & 3 & $"$ & $\ldots$ & $4.0-4.5$, \\
\hline, 1 & $\ldots$ & 5 & $"$ & $\ldots$ & $4: 3-6 \cdot 0$ \\
\hline , 2 & $\ldots$ & 2 & " & $\ldots$ & $4 \cdot 2-4 \cdot 5$, \\
\hline , 6 & $\ldots$ & 4 & " & $\ldots$ & $4 \cdot 0-6 \cdot 0$ \\
\hline, 10 & $\ldots$ & 17 & , & $\ldots$ & $4 \cdot 0-6 \cdot 5$, \\
\hline, 12 & $\ldots$ & 13 & $"$ & $\ldots$ & $4 \cdot 0-5 \cdot 0$ \\
\hline & & 48 & , & & \\
\hline
\end{tabular}

These were all placed in one table-tank measuring 5 feet by $2 \frac{1}{2}$ feet in area, and 1 foot 6 inches in depth. On March 21st, 1882, I measured these fish, or as many of them as I could catch, and found their lengths to vary from $5 \cdot 0$ to $12 \cdot 2 \mathrm{~cm}$. There were 37 of them : some of course had died. They had been fed with chopped marine worms.

The separate measurements were-

\begin{tabular}{|c|c|c|c|c|c|c|}
\hline 5.0 & $\mathrm{~cm}$. & $\ldots$ & $7 \cdot 1$ & $\mathrm{~cm}$. & $\ldots$ & $9 \cdot 1 \mathrm{cl}$ \\
\hline $5 \cdot 6$ & " & $\ldots$ & $7 \cdot 5$ & ", & $\ldots$ & $9 \cdot 1$ \\
\hline $5 \cdot 7$ & " & $\ldots$ & $7 \cdot 8$ & $"$ & $\ldots$ & $9 \cdot 2$ \\
\hline 6.0 & ", & $\ldots$ & $7 \cdot 8$ & ", & $\ldots$ & $9 \cdot 2$ \\
\hline $6 \cdot 1$ & " & $\ldots$ & $7 \cdot 8$ & " & $\ldots$ & $9 \cdot 4$ \\
\hline $6 \cdot 6$ & ", & $\ldots$ & $8 \cdot 7$ & , & $\ldots$ & $9 \cdot 8$ \\
\hline 66 & " & $\ldots$ & $8 \cdot 7$ & " & $\ldots$ & $9 \cdot 9$ \\
\hline $6 \cdot 9$ & " & $\ldots$ & $8 \cdot 8$ & " & $\ldots$ & $10 \cdot 1$ \\
\hline $7 \cdot 0$ & " & $\ldots$ & $8 \cdot 8$ & " & $\ldots$ & $10 \cdot 2$ \\
\hline $7 \cdot 0$ & " & $\ldots$ & $8 \cdot 8$ & ", & $\ldots$ & $11 \% 4$ \\
\hline $7 \cdot 0$ & " & $\ldots$ & $8 \cdot 9$ & " & $\ldots$ & $11 \cdot 6$ \\
\hline $7 \cdot 0$ & , & $\ldots$ & $8: 9$ & $"$ & $\ldots$ & $12 \cdot 2$ \\
\hline $7 \cdot 0$ & $"$ & $\cdots$ & & & $\cdots$ & \\
\hline
\end{tabular}

In my paper in the preceding number of this Journal, I recorded the fact, that some specimens of the dabs, 4.7 and $5.0 \mathrm{~cm}$. long, were taken in April and May, and stated that these must be a year old, because they could not reach that length if hatched in the same year. I also estimated the maximum length of specimens one year old at $13.5 \mathrm{~cm}$. These conclusions were founded entirely on specimens taken at sea; the growth of the above-recorded specimens in captivity fully comfirms my previous conclusions. None of the captive specimens showed any signs of sexual maturity, an indication that the dab does not any more than other flat-fishes begin to breed before it is two years old.

\section{Solea vulgaris, the Sole.}

I have not yet obtained young soles less than 1 year old at Plymouth, either in shallow or in deep water. Last summer I specially sought for them in deep water, but obtained none. There is some NEW SERIES.-VOL. II, NO. III. 
evidence now that during the summer aiter they are hatched they remain in shallow water.

Dr. Fulton states that eleven young soles, $2 \frac{3}{4}$ to 6 inches long, were taken in June in the Solway Firth, and that six soles, 5 to 7 inches in length, were taken in one morning's fishing on the Lancashire coast; but these are only soles about one year old, such as I stated in my previous paper to be taken in Plymouth Sound. But Mr. H. C. Sorby of Broomfield, Sheffield, has informed me that, in August 1890, he took several soles only about 2 inches long, in Bawdsey Haven in Suffolk. He sent me one specimen of these, and I found there was no doubt about its being of the species S. vulgaris. This specimen was $5 \mathrm{~cm}$., or 2 inches long, and having been captured in August must have been about 4 months old.

\section{Zeugopterus punctatus, Müller's Topknot.}

On July 9th, 1891, I took four specimens of this species in an otter trawl at a depth of 25 fathoms between the Eddystone and the Rame Head. These specimens measured $6 \cdot 2,6 \cdot 5,8 \cdot 2,9 \cdot 5 \mathrm{~cm}$. $(2 \cdot 4,2 \cdot 6,3 \cdot 2,3 \cdot 7$ inches) respectively. On March 21st, 1892, our fisherman took a specimen $8.4 \mathrm{~cm}$. long 6 miles from the breakwater. To my surprise this small specimen was a perfectly ripe female yielding ripe transparent ova on the slightest pressure. The ova were $.9 \mathrm{~mm}$ in diameter and contained a single oil-globule $.15 \mathrm{~mm}$. in diameter. The ova were evidently pelagic. Mr. George Brook has described the eggs of the other species $Z$. unimaculatus (Ichthyological Notes, Fourth Report of the Fishery Board for Scotland), and states that they were $.96 \mathrm{~mm}$. diameter in the preserved condition and had a single oil-globule. Brook obtained the eggs from a single ripe female 5 inches in length.

$Z$. punctatus reaches a maximum length of 7 or 8 inches, about 18 to $20 \mathrm{~cm}$. Those taken in July, 1891, may have been only one year and three or four months old, the ripe specimen being two years, but small for its age.

Scomber scobrus, the Mackerel.

\begin{tabular}{|c|c|c|c|c|c|c|c|}
\hline \multirow{2}{*}{ Date. } & \multirow{2}{*}{ Locality. } & \multirow{2}{*}{ 彳 } & \multicolumn{2}{|c|}{ Length. } & \multicolumn{2}{|c|}{ Weight. } & \multirow{2}{*}{ Age. } \\
\hline & & & Centimetres. & Inches. & Grammes. & Ounces. & \\
\hline $\begin{array}{c}1891 \\
\text { Sept. } 30\end{array}$ & $\begin{array}{l}\text { East side of Ply- } \\
\text { mouth Sound on } \\
\text { a whiffing line }\end{array}$ & 1 & $13 \cdot 8$ & $5 \cdot 4$ & - & - & $\begin{array}{l}1 \text { year and } 2 \\
\text { months. }\end{array}$ \\
\hline Oct. 5 & $\begin{array}{l}\text { Outside Sound, } \\
\text { whiffing lines }\end{array}$ & 4 & $\begin{array}{l}18,22 \cdot 6 \\
21 \cdot 9,25 \cdot 6\end{array}$ & $\begin{array}{l}7 \cdot 1,8 \cdot 9 \\
8 \cdot 6,10 \cdot 1\end{array}$ & - & - & $\begin{array}{l}1 \text { year and } 3 \text { or } \\
4 \text { months. }\end{array}$ \\
\hline
\end{tabular}




\begin{tabular}{|c|c|c|c|c|c|c|c|}
\hline \multirow{2}{*}{ Date. } & \multirow{2}{*}{ Locality. } & \multirow{2}{*}{ : } & \multicolumn{2}{|c|}{ Length. } & \multicolumn{2}{|c|}{ Weight. } & \multirow{2}{*}{ Age. } \\
\hline & & & Centimetres. & Inches. & Grammes. & Ounces. & \\
\hline 1891 & & & & & & & \\
\hline Nov. 3 & $\begin{array}{l}\text { Anchovy nets, } 1 \\
\text { mile outside Mew- } \\
\text { stone }\end{array}$ & 5 & $\begin{array}{l}15 \cdot 9 \text { to } \\
19 \cdot 5\end{array}$ & $\begin{array}{c}6.3 \text { to } \\
7 \cdot 7\end{array}$ & $\begin{array}{c}24.0 \text { to } \\
4.8 \cdot 9\end{array}$ & 8 to $1 \cdot 7$ & $\begin{array}{l}1 \text { year and } 4 \\
\text { months. }\end{array}$ \\
\hline Nov. 4 & $\begin{array}{l}\text { Anchovy nets, off } \\
\text { Rame Head }\end{array}$ & 6 & $\begin{array}{c}16 \cdot 7 \text { to } \\
20 \cdot 7\end{array}$ & $\begin{array}{l}6.6 \text { to } \\
8 \cdot 2\end{array}$ & 一 & 一 & ", \\
\hline Nov. 5 & $\begin{array}{l}\text { Anchovy nets, off } \\
\text { Bigbury Bay }\end{array}$ & 33 & $\begin{array}{l}15 \cdot 1 \text { to } \\
21 \cdot 0\end{array}$ & $\begin{array}{c}5 \cdot 9 \text { to } \\
8 \cdot 3\end{array}$ & - & - & " \\
\hline Nov. 16 & $\begin{array}{l}\text { Anchovy nets, } \\
\text { south of the Ed- } \\
\text { dystone }\end{array}$ & 1 & $19 \cdot 8$ & $7 \cdot 8$ & - & - & , \\
\hline Nov. 23 & $\begin{array}{l}\text { Anchovy nets, off } \\
\text { Rame Head }\end{array}$ & 4 & $\begin{array}{c}17 \cdot 1 \text { to } \\
18 \cdot 5\end{array}$ & $\begin{array}{c}6 \cdot 7 \text { to } \\
7 \cdot 3\end{array}$ & - & - & ", \\
\hline June 10 & $\begin{array}{l}8 \text { miles outside } \\
\text { Eddystone, whiff- }\end{array}$ & 7 & $\begin{array}{c}22 \cdot 2 \text { to } \\
23 \cdot 5 \text {, one } \\
26 \cdot 3\end{array}$ & $\begin{array}{l}8 \cdot 7 \text { to } \\
9 \cdot 3 \\
10 \cdot 3\end{array}$ & $\begin{array}{l}85 \text { to } \\
106 \cdot 3, \\
134: 5\end{array}$ & $\begin{array}{c}3 \text { to } 3 \frac{3}{4}, \\
4 \frac{3}{4}\end{array}$ & 1 year. \\
\hline June 23 & $\begin{array}{l}\text { Mackerel nets, } 20 \\
\text { to } 30 \text { miles south } \\
\text { of Eddystone }\end{array}$ & $\begin{array}{l}5 \\
1\end{array}$ & $\begin{array}{l}29 \cdot 5 \text { to } \\
32 \cdot 8 \\
42 \cdot 5\end{array}$ & $\begin{array}{c}11.6 \text { to } \\
12.9 \\
16.7\end{array}$ & $\begin{array}{l}163 \text { to } \\
255 \cdot 1 \\
524 \cdot 4\end{array}$ & $\begin{array}{c}7 \frac{1}{4} \text { to } 9 \\
18 \frac{1}{2}\end{array}$ & $\begin{array}{l}2 \text { years. } \\
2 \text { years. } \\
3 \text { years. }\end{array}$ \\
\hline May 27 & Off Looe Island & 2 & $30 \cdot 5,31 \cdot 3$ & $12,12 \frac{1}{2}$ & $\begin{array}{c}205 \cdot 5 \text { to } \\
230 \cdot 3\end{array}$ & $7 \frac{1}{4}, 8 \frac{1}{8}$ & 2 years. \\
\hline May 27 & $\begin{array}{l}80 \text { miles south- } \\
\text { west of Penzance }\end{array}$ & 2 & $43 \cdot 2,44 \cdot 5$ & $17,17 \frac{1}{2}$ & $\begin{array}{c}673.3 \text { to } \\
683.9\end{array}$ & $23 \frac{3}{4}, 24 \frac{1}{8}$ & 3 or 4 years. \\
\hline
\end{tabular}

The spawning period of the mackerel in the vicinity of Plymouth lasts from the middle of May to the end of July, these being its extreme limits. As there is no difficulty in obtaining any number of mackerel during the spawning time, the fish being taken for the market in large numbers in the ripe condition, the evidence available for the determination of the period is abundant. It would be expected that the age of young mackerel could easily be reckoned from such a short and definite spawning season. But I have not found it very easy up to the present time. More abundant data will require to be collected before the question can be satisfactorily answered. In the meantime the few observations in the above table are sufficiently interesting to be recorded, and from them a probable rate of growth can be deduced which may be tested by future observations.

The specimens of the entry for June 23rd in the table were selected by myself on board a mackerel boat. The boat sailed from Plymouth on June 20th, but the nets were not shot that night because there was not wind enough to enable us to get as far as was necessary. During the whole of the next day we were sailing under a light breeze catching mackerel by hook on whiffing lines. We took 150 in this manner, the bait being a slice from the silvery belly or tail of a mackerel already caught. Some of these mackerel were rather small, but the majority were large, and the great 
majority were ripe males ; there was not a single ripe female among them, but a few unripe. It may be concluded from this that the males continue feeding when ripe, but the females do not. In the evening we shot the drift-nets, and, on hauling them next morning, got about 150 mackerel, among which were many ripe and many spent. The males were more numerous than the females in this lot also. Of the seven I took for examination six were selected as the smallest of the catch, and the other as a specimen of the larger sort. The condition and dimensions of these specimens were-

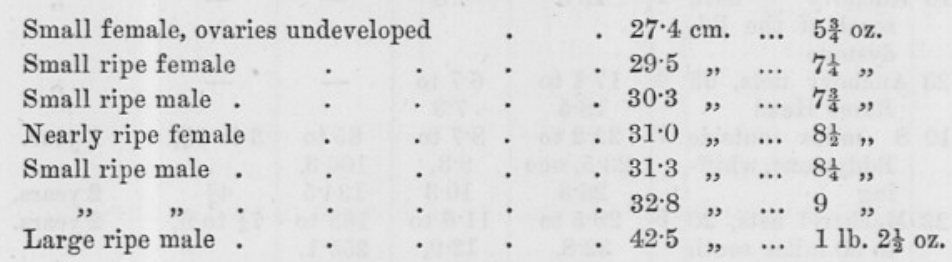

Thus the smallest ripe female taken on this occasion was $29 \cdot 5 \mathrm{~cm}$. long $\left(11.6\right.$ inches) and $7 \frac{1}{4} \mathrm{oz}$. in weight. The female of $5 \frac{3}{4} \mathrm{oz}$. was not shotten and apparently would not have spawned that season, the ovaries being quite undeveloped. The first question to be considered is, assuming about 11 inches to be the length of the smallest mature female, whether this size is usually reached in one year. We have no reason at present to suppose that the mackerel reaches maturity more rapidly than the herring, and I have, therefore, estimated the age of these mackerel, $29.5 \mathrm{~cm}$. to $32.8 \mathrm{~cm}$. in length, at two years. On June 10th, during the spawning period, six specimens were taken of 22.2 to $23.5 \mathrm{~cm}$. in length, and whose weight did not exceed $3 \frac{3}{4} \mathrm{oz}$. These must have been one year old at least ; they showed no signs of sexual maturity, and I have provisionally estimated their age at one year only. Then we have the specimens taken in the anchovy nets in November. I was at first inclined to conclude that these came from the spawning of the previous June or July. But this would make the growth extraordinarily rapid. Mr. Dunn, of Mevagissey, has seen young mackerel of this size in November, and it is his opinion that they are only five months old. The account of the growth given by Day, on Dunn's authority, is that the young are plentiful in the bays in August and September, when they are about 3 inches long, reaching 6 or 7 inches in November; then they leave for the deep sea and reappear the following June, when they are 8 or 9 inches long. According to this reasoning they would increase 3 or 4 inches in length in the two months October and November, and only 2 inches in the seven months between November and June. This is manifestly improbable, and there are various considerations to support the con- 
clusion that these young mackerel of November are really more than a year old, and are derived from the spawning not of the immediately preceding summer but of the previous year. I have shown that the scad (Caranx trachurus), which I believe spawns about the same time as the mackerel, is only 2.5 to $3.5 \mathrm{~cm}$. long in September (see my previous paper). The herring is ouly 8 to $9 \mathrm{~cm}$. long in November when spawned in April or May: the adult mackerel is about six inches longer than the adult herring, and therefore there is no reason to believe that it grows to twice the length in less time.

But the question arises, if these mackerel 16 to $21 \mathrm{~cm}$. are sixteen months old, how can others taken in June and 22 to $23 \mathrm{~cm}$. long be only a year old? The answer to which is, I think, that there is considerable individual variation in size. It it clear that the single specimen, taken at the end of September and measuring $13.8 \mathrm{~cm}$., could not have reached that length in two or three months, and it must have been an unusually small specimen at fourteen months old.

I hope to test and confirm these conclusions this summer by following the growth of the mackerel fry from the hatching time onwards. Hitherto, mackerel fry from a few weeks upwards have not been taken, but by the use of a large and suitable net we may succeed in capturing them.

In the early summer the smaller mackerel, those I conclude to be two years old, are found near the coast, while the larger fish are caught out in the open sea. Thus in May last year Plymouth boats were catching mackerel of 12 or 13 inches in length, and about $\frac{1}{2} \mathrm{lb}$. in weight, off Looe Island on the Cornish coast, while the large Lowestoft boats were bringing in huge mackerel up to more than $1 \frac{1}{2} \mathrm{lbs}$. in weight from off Ushant and eighty miles south-west of Penzance.

\section{Clupea harengus, the Herring.}

I have not had many opportunities of studying the growth of the herring, but have thought it would be useful to give an inclusive summary of the evidence which has been recorded by others on the subject. The question has been carefully and successfully investigated by H. A. Meyer, in the Baltic. There is a paper by this observer in the Jahresbericht of the Commission zur Untersuchung der deutschen Meere, for 1874-75-76, published in 1878. The paper is entitled Observations on the Growth of the Herring in the Western Part of the Baltic. Before Meyer's work various contradictory opinions had been expressed concerning the growth of the herring. For instance, the English Royal Commission of 1862, whose report was published in 1863 (Commission on the Operation of the 
Acts relating to Trawling for Herring on the Coasts of Scotland), say that there is reason in Messrs. Yarrell and Mitchell's supposition that herring attain to full size and maturity in eighteen months, but there is no good evidence against the supposition that it reaches its spawning condition in one year. The Commissioners argue that the egg of the herring is hatched in two or three weeks, and that the young attain 3 inches in length in six or seven weeks after hatching, and that in nine months more they would reach 10 or 11 inches in length. In any case eighteen months is to be regarded as the maximum time required by the herring to reach maturity.

Axel Boeck, on the other hand, the Norwegian naturalist, concluded that mature herring were not less than three or more than four years old.

Meyer states that the spawning of spring herring in the Schlei begins in March, but takes place principally in April and May. At the end of May, 1874, he found in the Great Belt near Schleswig many larvæ 2.5 to $2.9 \mathrm{~cm}$. long, on the 10th June $3.3 \mathrm{~cm}$., and on 23rd June $4.3 \mathrm{~cm}$. long. Likewise on 10th June, 1876, he captured larvæ up to $3.8 \mathrm{~cm}$. long, but the majority were only 2.5 to $2.8 \mathrm{~cm}$. If the longest of these came from eggs shed in March they could not be more than three months old, which would give an increase of $1.3 \mathrm{~cm}$. per month. But the majority 2.5 to $2.3 \mathrm{~cm}$. long observed on the 10th June could not be more than six weeks old, which gives an increase of 1.7 to $1.8 \mathrm{~cm}$. for the month.

After about two months of age the herring changes from a transparent elongated larva without scales, and very different in appearance to the adult herring, to the permanent form of the adult. The metamorphosed young are much deeper and thicker in proportion to their length than the younger larvæ. The change of form and acquisition of the silvery livery takes place in the Schlei in July, and by the end of that month the greater number of the spring brood have passed the intermediate stage; they are then 4.5 to $5.5 \mathrm{~cm}$. long. This process of change and the growth during it were watched in specimens kept in captivity in a floating box, the specimens grew from 2.5 to $2.8 \mathrm{~cm}$. on the 11 th June to 4.5 to 4.6 $\mathrm{cm}$. on 1st August. At this length they were fully scaled.

In July and August larger young herrings of 7 to $9 \mathrm{~cm}$. long $(2.5$ to 3.7 inches) are found mixed with the smaller, and evidently come from an earlier spawning. It is certain that the young from the spring spawning, mostly 6.0 to $7.0 \mathrm{~cm}$. in length, leave the Schlei for the Baltic at the end of August and beginning of September. From this time on these young fish show themselves in numbers in all the bays of the Western Baltic, but mixed with another generation of somewhat larger fish, from which they are 
separated by no evident limit. Meyer, therefore, measured the growth by taking the lengths of the smallest fish in each catch. Thus the growth of the smallest fish is shown by the following figures :

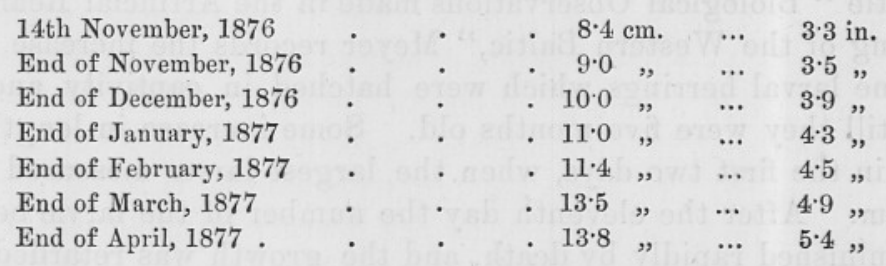

This gives an increase of $1.0 \mathrm{~cm}$. per month, but of course, since the variation in size of fishes of the same age is considerable, the mean growth of the young from the spring spawning was somewhat greater. Two rearing experiments made by Meyer for comparison gave a mean result of 1.07 and $1.1 \mathrm{~cm}$. per month respectively; the experiments lasted four and a half and three months respectively.

Concerning the autumn herring, which spawns in the open sea in September and October, Meyer has no very conclusive observations, but the evidence he has indicates that the growth of these is equal to or rather greater in one year than that of the spring herring, the adults being somewhat larger than in the case of the latter. $\mathrm{He}$ points out that some herring spawn later than October, even as late as December, so that it is impossible to separate the broods with certainty. He also remarks that the spring herring, between six months and a year old, are not definitely separated in size from the smallest autumn herring of the preceding autumn; and as he took the smallest specimens only for his measurements, we must conclude that the average size of spring herrings at one year old is greater than 5.4 inches; we may, perhaps, put the average size at 6 to $6 \frac{1}{2}$ inches, and the maximum at 7 .

Meyer proceeds to discuss the amount of growth in the second year, and the age at which puberty is attained in the herring. In his collection, the smallest ripe herrings were $20 \mathrm{~cm}$. long $(7 \cdot 9$ inches) while those of 21 to $22 \mathrm{~cm}$., were not rare. Ljungmann states that some herrings off the coast of Sweden are ripe at $17 \cdot 5$ or even 16 $\mathrm{cm}$. length. Meyer argues that, taking $20 \mathrm{~cm}$. as the limit, the yearold fish have only 6 or $7 \mathrm{~cm}$. to add to their length in order to reach it. But he regards it as impossible that the young of the spring-spawning herring should become autumn-spawning herring or vice versâ, and since the majority of the herrings which spawn for the first time are more than $20 \mathrm{~cm}$. long, he believes they spawn first at two years old. Meyer does not mention the consideration that an increase of half the total length may, and generally does 
mean a doubling of the weight; unfortunately the weight of the fish does not enter into his calculations, but I have no doubt he is perfectly right in his conclusion.

In another paper published separately in octavo in 1878, under the title "Biological Observations made in the Artificial Rearing of Herring of the Western Baltic," Meyer records the increase in size of some larval herrings which were hatched in captivity and kept alive till they were five months old. Some increase in length took place in the first two days, when the largest larvæ measured $9 \cdot 2$ to $9.3 \mathrm{~mm}$. After the eleventh day the number of the larvæ began to be diminished rapidly by death, and the growth was retarded. On the forty-seventh day after fertilization, the young fish measured only $1.2 \mathrm{~cm}$., while according to the observations of the free specimens in the Schlei the length should have been $1.7 \mathrm{~cm}$. The water was now supplied unfiltered and abounding in Copepoda and other small pelagic animals, whereupon the young fish began to grow with very great rapidity, and at the end of five months were as large as their free-living brethren in the Schlei. The lengths observed in the free and the captive specimens were as follows:

Age from fertilization
of the eggs.
1 month
2 months
3 ,"
4
5

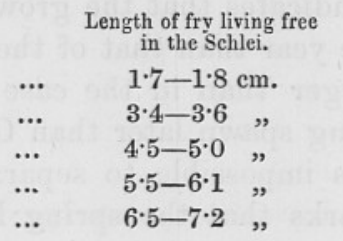

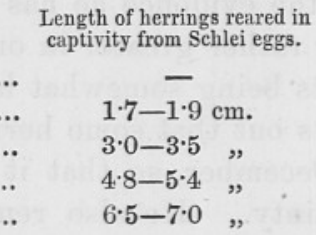

Thus it will be seen that the young fish in captivity, when they obtained suitable food in abundance, made up for lost time, and at the end of five months were as large as the fish living under natural conditions. From the remarkable rapidity with which these young herrings, after being stunted for a time by want of nourishment, caught up in growth with the free-living fish of the same age, Meyer draws the conclusion that the rate of growth in the herring depends largely on the quantity of food available, and as the latter must be greater in summer than in winter, the rate of growth of the fish must vary at different seasons of the year and in different years, so that only an average rate of growth can be determined.

At Plymouth I have only once seen a number of half-grown herring captured. This was on May 16th, 1889, when I watched a ground-seine being hauled on the south shore of the Cattewater. Some hundreds of herring were brought on shore, and I secured a sample of twenty-four, which measured 11 to $14 \mathrm{~cm}$. $(4 \cdot 3$ to $5 \cdot 5$ inches) in length. Now the spawning of herring at Plymouth takes place principally in Bigbury Bay in January and February. I 
have observed the evidence of this in ripe and spent herrings brought to market almost every year, but paid particular attention to it in 1888 and 1889 . In $1888 \mathrm{I}$ found the spawning continued to the middle of March, and on April 9th, 1891, I examined six ripe herring taken eight miles off Dodman Point in Cornwall, and sent to the Laboratory by Mr. Dunn. In these last specimens the ovaries were burst and the eggs dead in the body-cavity. $\mathrm{Mr}$. Dunn thought that the oviducts were obstructed, and that the eggs had died during the life of the fish, but the condition observed might have been merely due to rough handling at capture. In any case this is an indication that some herrings are spawning on the southwest coast in April, and others may be spawning in May. On the other hand, I have met with no indication whatever that there are any herrings spawning on our south-west coast in autumn. I can only conclude that the herrings above mentioned taken in May were about one year old, though the smallest, $11 \mathrm{~cm}$. long, are smaller than the smallest found by Meyer to be one year old.

In September and October 1890, Professor Weldon measured a number of herring brought to the Laboratory, and taken in seines in the Cattewater and Hamoaze. The total lengths were-

From Cattewater in September, twenty-three specimens measured $17 \cdot 5$ to $21 \cdot 8 \mathrm{~cm}$. $(6 \cdot 9$ to $8 \cdot 6$ inches $)$.

From Hamoaze on October 10th, eleven specimens measured $19 \cdot 4$ to $27 \cdot 7 \mathrm{~cm}$. $(7 \cdot 6$ to $10 \cdot 9$ inches $)$.

From Hamoaze October 14th, thirty-two specimens measured 12.8 to $21 \cdot 8 \mathrm{~cm}$. (5.0 to $8 \cdot 6$ inches).

There is here a great range in size; it is possible that the smallest, those 5 inches long, were only nine months old, having been hatched in the preceding January, and that the largest, about 26 or $27 \mathrm{~cm}$. long, were in their third year. But I think it is almost certain that the majority, ranging from 19 to $23 \mathrm{~cm}$. in length, were one and three quarter years old, and would complete their two years in the following spawning season, January to March.

These herrings taken in Hamoaze and Cattewater are locally known as habour herring; but adult herrings of a considerable range in size occur in great abundance in Plymouth Sound every autumn and winter, though they always leave the Sound for the open coast before spawning. I see no reason at present to suppose that the herring which ascend the estuaries are of a different race from those which remain in the Sound, although perhaps the younger individuals penetrate further into brackish water than the older.

It is of considerable interest to study the records published in the Reports of the Scottish Fishery Board of young herring taken in 
the sprat and whitebait fisheries, in relation to the conclusions summarised above as to the rate of growth of herring in the Baltic. These records were collected for an entirely different purpose, namely, to ascertain the destruction of herring fry entailed by the fisheries mentioned, but they afford valuable evidence on the growth and distribution of young herring. The first of the papers to which I refer is a Report on the Sprat Fishing on the East Coast of Scotland in the winter of 1883-84, by the late Mr. J. Duncan Matthews, Second Annual Report of the Fishery Board for Scotland. We find from this paper that in December, January, and February samples were taken at random from the fish taken by the sprat boats using " circle nets" in the Firth of Forth. Of 1671 fish examined in December, 12.8 per cent. were herrings $3 \frac{1}{4}$ to $5 \frac{1}{4}$ inches long, the percentage in the several samples ranging from 1.5 to 76.4 . In January and February the percentage of herrings was considerably smaller, and the size a little greater, namely, from $3 \frac{1}{2}$ to $5 \frac{3}{4}$ inches. Now there is a thoroughly investigated spawning ground about the Isle of May at the mouth of the Firth of Forth, where herrings spawn every year from the end of January to the end of March, or even later. It is obvious that the size of the largest of the young herrings just mentioned agrees exactly with that of the Baltic spring herrings when one year old. But the question arises, are not the smallest, $3 \frac{1}{4}$ inches, too small to be derived from the spring spawning in the Firth of Forth? If spawned in March then in December they would be nine months old, and the size of herring at nine months given by Meyer is 3.9 inches. The agreement is, therefore, very close, and we may conclude that the herring measured by Matthews were derived from the spawn shed at the Isle of May in the previous spring. The autumn spawning on the coast of Scotland takes place in August and September, and there is no great fishery at this time in the immediate neighbourhood of the Firth of Forth. Moreover, young herring hatched in August would be less than 3 inches long in December.

A similar examination with similar results was made of the sprat fishing in the Firth of Tay. The samples were taken in every month from November to February, from the fish captured by the fixed bag-net, and the percentage of young herrings in the samples varied from three to eighty. The herrings were between $3 \frac{1}{4}$ and $5 \frac{1}{2}$ inches in length. But we have no definite indication of spring spawning at the mouth of the Tay. It is possible enough that the young herring taken in the Tay were originally derived from the same spawning beds as those in the Forth, namely, the ground around the Isle of May. However, there is no doubt that herrings spawn in spriug at various places along the east coast of Scotland, 
as well as at the Isle of May, although except at the latter place observations on the subject are vague and indefinite.

We pass on now to another paper, namely, one by J. C. Ewart and J. Duncan Matthews in the Fourth Report of the Scottish Fishery Board, on the Nature of Thames and Forth Whitebait. The whitebait fishing in the Forth is not, from the present point of view, of great importance. The authors inform us that it is carried on in the Forth between Alloa and Kincardine in the winter months, and the fish captured vary very little in kind; 2600 specimens were examined in samples of about 200 each during December, January, and February, and $99 \frac{1}{2}$ per cent. of the whole number consisted of sprats, only about half a dozen herrings being found among them.

The results of the examination of Thames whitebait were very different. These results may be conveniently tabulated thus:

\begin{tabular}{|c|c|c|c|c|c|c|}
\hline Month. & & $\begin{array}{l}\text { No. } \\
\text { xamined. }\end{array}$ & & rin & & Length of herrings. \\
\hline February & $\ldots$ & 1400 & $\ldots$ & 7 & $\ldots$ & Some under 2 inches. \\
\hline March & $\ldots$ & 1200 & $\ldots$ & 5 & $\ldots$ & Some nearly 4 inches. \\
\hline April & $\ldots$ & 800 & $\ldots$ & 14 & $\ldots$ & $\begin{array}{l}12 \text { per cent. of the herrings under } 1 \frac{1}{2} \text { inches } \\
\text { without scales. }\end{array}$ \\
\hline May & $\ldots$ & 600 & $\ldots$ & 30 & $\ldots$ & $\begin{array}{l}40 \text { per cent. of the herrings } 2 \text { inches long } \\
\text { and completely scaled; } 60 \text { per cent. } 1 \frac{1}{2} \\
\text { to } 1 \frac{3}{4} \text { inches, and only partly scaled. }\end{array}$ \\
\hline June & $\ldots$ & 800 & $\ldots$ & 87 & $\ldots$ & $\begin{array}{l}60 \text { per cent. of the herrings were fully scaled } \\
\text { and from } 2 \text { to } 2 \frac{1}{4} \text { inches long; } 40 \text { per cent. } \\
1 \text { to } 1_{2}^{\frac{1}{2}} \text { inches, scaleless, or nearly so. }\end{array}$ \\
\hline July & $\ldots$ & 600 & $\cdots$ & 75 & $\cdots$ & $1_{2}^{1}$ to $2 \frac{1}{2}$ inches; 80 per cent. under 2 inches. \\
\hline August & ... & 500 & $\ldots$ & 52 & $\ldots$ & 2 to 3 inches. \\
\hline
\end{tabular}

The remainder of the samples in every case consisted of course of young sprats, and with these I shall deal in discussing the growth of that species. The observations on the herring are extremely interesting and instructive, notwithstanding the fact that the observers were not attending to the question of the rate of growth, and have not therefore given as complete an account of the sizes and conditions as that question demands. The authors of the paper merely remark that the young herring would appear to be developed from spawn deposited during the spring months. We see from the above table that Ewart and Matthews place the limit of size between what we may call larval herring (those witbout scales and without the silvery livery) and the fully-developed herring at 2 inches, and this agrees with Meyer's observation that the fully-developed young fish were 1.8 to $2 \cdot 2$ inches long. The change is completed in the third month of age according to Meyer.

In February and March the number of larval herring was extremely small, the total number of herrings in a catch being 7 and 
5 per cent. and only a few of these under 2 inches. The appearance of the fry can scarcely be said to have commenced, only a precocious individual or two having spawned. In April the fry just begin to appear, 14 per cent. herrings are caught, but only 12 per cent. of these are scaleless larvæ. These must have been one to two months old. The larger herrings, over 2 inches long, taken at this time we need not consider at present. In May we have 30 per cent. herrings and 60 per cent. of these are larvæ; that is, 18 per cent. of the total catch are larval herrings. In June we find that 34.8 per cent. of the total catch are larval herring. In July, according to the figures given, the number of larval herring is increased to 60 per cent. of the total catch, while in August there are no larval forms at all. I am obliged to conclude that there is a mistake in the figures for July; probably the number of larvæ declines in that month, and it ought to be " 80 per cent. of the herrings caught were over two inches" instead of " under." Making this correction we find the larval herrings were 15 per cent. of the total catch.

If we write down the total number of young herrings under 3 inches, the number of scaleless forms, and the number of scaled forms, all as percentages of the total catch, side by side we get-

$\begin{array}{lcccccccc} & & & & \text { Total number. } & & \text { Larral forms. } & & \text { Scaled forms. } \\ \text { April } & . & . & . & 14 & \ldots & 1 \cdot 6 & \ldots & 12 \cdot 4 \\ \text { May } & . & . & . & 30 & \ldots & 18 & \ldots & 12 \\ \text { June } & . & . & . & 87 & \ldots & 34 \cdot 8 & \ldots & 42 \cdot 2 \\ \text { July } & . & . & . & 75 & \ldots & 60(15) & \ldots & 15(60) \\ \text { August } & . & . & . & 52 & \ldots & 0 & \ldots & 52\end{array}$

Assuming that the alteration I have made is correct we find that the number of larval herrings reached a maximum in June, and that these were almost entirely absent in April and August. It is not clear that the 12.4 per cent. of scaled herrings in April were not over 3 inches long and derived from some spawning in the previous year. Leaving these aside, therefore, we find the scaled young under 3 inches long reach a maximum in July, and slightly decrease in August. But the latter decrease is doubtless only apparent, many of the larger individuals of this season's brood having changed their locality and being no longer caught in the whitebait nets.

If we had any reliable information concerning a spring spawning of herring at the mouth of the Thames, we could reckon from the time of this spawning the age of the herring fry taken as whitebait. But I have been unable to find anywhere any record of observations on the spawning of herring in this neighbourhood in spring. All that is stated in Holdsworth's work on Deep Sea Fishing and 
Fishing Boats, and Day's History of British and Irish Fishes, is that the herring spawns at Ramsgate in October and November. I can, therefore, only assume the correctness of Meyer's conclusions as to the rate of growth, and from the size of the herring fry measured by Ewart and Matthews, calculate the period at which the spawning occurred from which they were derived.

The larval herring occurring in June were about two months old, some more and some less. This shows that the spawning took place most abundantly in April, while the larval forms taken in May and July must have come from spawn deposited in March and May. Thus all the eggs shed in March and April had become scaled young herrings over 2 inches long in July, constituting 60 per cent. of the catch of the stow-nets, while the 15 per cent. larval forms taken with them came from the last eggs of the season deposited in May. In August no larval forms still unmetamorphosed were left, all the young herrings had undergone their transformation from the naked transparent larval condition to the scaled silvery little fish similar to the adult herring except in size.

There must be then a spring spawning of herrings somewhere near the mouth of the Thames, taking place in March, April, and May. The larger young herring taken in March and April are probably derived from the autumn spawning which takes place off Ramsgate in October and November. Now if we take October as the principal month of the autumn spawning, it is just six months from that month to April, the principal month of the spring spawning, which is a confirmation of the conclusions we have drawn as to the occurrence of the latter. It is surprising that no direct observations have ever been made on this spring spawning of herrings at the mouth of the Thames.

\section{Clupea sprattus, the Sprat.}

The character of the spawn of the sprat, and the period at which spawning takes place, have been determined in several localities by direct observation, and there are also a certain number of observations on record from which we may draw some conclusions as to the rate of growth of the species.

The paper on Whitebait, by Messrs. Ewart and Matthews, so largely used in the previous discussion of the growth of the herring, also supplies valuable observations on young sprats ; 2600 specimens of whitebait procured from the Firth of Forth, between Alloa and Kincardine, in December, January, and February, consisted almost entirely (991 per cent.) of young sprats measuring $1 \frac{3}{8}$ to $2 \frac{3}{4}$ inches in length. The authors themselves point out that in a previous 
paper, Matthews had published evidence concerning the spawning season of the sprat which would make these whitebait sprats six to eight months old. These authors do not always bear in mind that the spawning season of the sprat may differ in different places, but Matthews states in the earlier paper (Sprat-fishing, Second Report, Scottish Fishery Board), that he received ripe sprats from Stonehaven, Girvan, and the Firth of Forth only in May and June. I myself took the pelagic eggs of the sprat in the lower part of the Firth of Forth in May and June. Thus we have in this case, the maximum growth of the sprat, that of one spawned in June, and measuring $2 \frac{3}{4}$ inches in the following December, $2 \frac{3}{4}$ inches in six months, and the minimum, that of one spawned in May, and measuring $1 \frac{3}{4}$ inches in the following February, $1 \frac{3}{4}$ inches in nine months. The authors do not give separate measurements for the separate months of observation. If we take the mean, both of time and size, we have a length of $2 \frac{1}{16}$ inches at seven and a half months of age; and the paper itself states that over 70 per cent. of the sprats examined were from 2 to $2 \frac{1}{4}$ inches. The herring at seven and a half months, according to Meyer's results, measures about $3 \frac{1}{2}$ inches.

The observations on the sprats in the Thames whitebait are mor detailed, though by no means so much so as the present subject requires. I have tabulated them as follows:

\begin{tabular}{|c|c|c|c|c|c|c|}
\hline Month. & & Total. & \multicolumn{3}{|c|}{ Percentage of sprats. } & Size of sprats. \\
\hline February & $\ldots$ & 1400 & $\ldots$ & 93 & $\ldots$ & 2 to 3 inches. \\
\hline March & $\ldots$ & 1200 & $\ldots$ & 95 & $\ldots$ & 2 to $2 \frac{1}{2}$ inches. \\
\hline April & $\ldots$ & 800 & $\ldots$ & 86 & $\ldots$ & 2 inches average. \\
\hline May & $\ldots$ & 600 & $\ldots$ & 70 & $\ldots$ & $2 \frac{1}{2}$ inches. \\
\hline June & $\ldots$ & 800 & $\ldots$ & 13 & $\ldots$ & $\begin{array}{l}1 \text { to } 2 \frac{1}{4} \text { inches, the } \\
\text { smaller without } \\
\text { scales. }\end{array}$ \\
\hline July & $\ldots$ & 600 & $\ldots$ & 25 & $\ldots$ & $\begin{array}{l}8 \text { per cent. of the } \\
\text { sprats under } 1_{4}^{\frac{1}{4}} \\
\text { inches, without } \\
\text { scales. }\end{array}$ \\
\hline August & $\ldots$ & 500 & $\ldots$ & 48 & $\ldots$ & 1 to $1 \frac{1}{2}$ inches. \\
\hline
\end{tabular}

The number of small scaleless sprats gradually increased during the last month, until 90 per cent. of the samples consisted of these.

The young sprat undergoes a metamorphosis from the naked larval form to the silvery scaled form like the herring, and we see that the young larvæ which began to appear in the Thames in June reached 8 per cent. of the total number of sprats in July, and 90 per cent. of "the samples" in August. It seems as if the total catch was meant by the latter expression, but the meaning may be, 
as seems more probable, that 90 per cent. of the sprats alone were young larval forms. We may, I think without much error, assume that the larval sprats were about two months old, as in the case of the herring, and it follows that the spawning of the sprats took place chiefly in June, but occurred also in April and May. I do not know at present to what extent the larger fish are separated from the total catch of the stow-nets before the whitebait are sent to market. But at any rate we know of only one spawning season for sprats, which extends over three or four months, and, therefore, the sprats taken in February, measuring 2 to 3 inches, were doubtless spawned between April and June in the previous year. Thus they were seven to ten months old. Again we may reasonably argue that the sprats taken in April and May before the larvæ of the season had begun to appear, were derived from the previous year's spawning, and were, therefore, about one year old, so that the average size of year-old sprats is not much above $2 \frac{1}{2}$ inches. Unfortunately, the size of the year-old sprats taken in June and July is not given; those of $2 \frac{1}{4}$ inches, taken in June must have been a year old, but larger ones may have been picked out before the samples of whitebait were taken. It is clear in any case that a great number of sprats do not exceed $2 \frac{1}{4}$ to $2 \frac{1}{2}$ inches at the age of one year, but what the maximum growth may be is not determined.

My own observations on young sprats at Plymouth are not numerous; I have only obtained specimens on the following occasions :

November 21 st, 1889 , thirty-three specimens $5 \cdot 5$ to $6 \cdot 6 \mathrm{~cm}$. $(2 \cdot 2$ to $2 \cdot 6$ inches) taken in shrimp-trawl in Cawsand Bay.

December 4 th, 1889 , four specimens, $5 \cdot 7$ to $6 \cdot 2 \mathrm{~cm}$. $(2 \cdot 2$ to $2 \cdot 4$ inches) a sample from a large number killed in the Millbay Docks by blasting under water when I was present.

April 3rd, 1891, thirteen specimens, 8.5 to $9.8 \mathrm{~cm}$. $(3.3$ to 3.8 inches), caught in a bucket from the side of a boat off Rame Head; sample from a much larger number.

At Plymouth the sprat commences to spawn at the end of January, and the floating ova are found in February, March, and April, so that I think the above specimens registered above were a little less and a little more than a year old respectively.

The only evidence at present available as to the size at which sprats become sexually mature is that of Matthews in his paper in the second Report of the Scottish Fishery Board. He states that of the sprats he obtained from the Forth, only one was 6 inches long, and only two or three $5 \frac{1}{2}$ inches, all those near maturity measuring 4 to $4 \frac{1}{2}$ inches. It appears, therefore, that small as the adult sprat is it does not reach its mature size in one year, that it is 4 inches 
long or very nearly so before it begins to spawn, and does not exceed 3 inches when one year old. It is therefore a probable conclusion that, like the herring, the sprat begins to breed when it is two years old.

\section{Pleuronectes microcephalus, the Merry-sole.}

Mr. Holt gives 8 inches as the length of the smallest ripe female of this species obtained by him on the west coast of Ireland.

On March 30th, 1892, I measured two ripe females at Plymouth obtained from a trawler, their lengths were 20.8 and $22.8 \mathrm{~cm}$., or $8 \cdot 2$ and 9.0 inches. The minimum size of mature females is about the same, therefore, on the south coast of England as on the west coast of Ireland. In my previous paper I recorded the length of the smallest ripe male, namely $6 \cdot 4$ inches.

\section{Clupea pilchardus, the Pilchard.}

In the preceding number of this Journal I discussed very briefly the early growth of the pilchard, while describing some young stages of the fish which I had taken in the tow-net. I have now to record some further evidence concerning the life-history of this species. Last summer small-meshed drift-nets were obtained for the purpose of the anchovy investigation, and when these were shot from time to time during the autumn and winter, besides other fish a considerable number of small pilchards were taken in them. For details as to nets see paper on Experiments on the Relative Abundance of Anchovies off the South Coast of England by Mr. Calderwood, in the present number, p. 10. The number and size of the pilchards taken at each shot of these nets in November and December 1891, and January 1892, are shown in the following table.

\begin{tabular}{|c|c|c|c|c|c|c|}
\hline \multirow{2}{*}{ Date. } & \multirow{2}{*}{ Locality. } & \multirow{2}{*}{ Number. } & \multicolumn{2}{|c|}{ Length. } & \multicolumn{2}{|c|}{ Weight. } \\
\hline & & & Centimetres. & Inches. & Grammes. & Ounces. \\
\hline 1891 & & & & & & \\
\hline Nov. 3 & $\begin{array}{l}1 \text { mile south of Mew- } \\
\text { stone }\end{array}$ & $\begin{array}{r}507 \\
40\end{array}$ & $\begin{array}{c}13 \cdot 0 \text { to } 16 \cdot 2 \\
18 \cdot 3 \text { to } 22\end{array}$ & $\begin{array}{l}5 \cdot 1 \text { to } 6 \cdot 4 \\
7 \cdot 2 \text { to } 8 \cdot 7\end{array}$ & $\begin{array}{l}14 \cdot 2 \text { to } 30 \cdot 5 \\
59 \cdot 6 \text { to } 84 \cdot 8\end{array}$ & $\begin{array}{l}55 \text { to } 1 \cdot 07 \\
2 \cdot 09 \text { to } 2 \cdot 9\end{array}$ \\
\hline Nov. 4 & Off Rame Head & $\begin{array}{r}19 \\
7\end{array}$ & $\begin{array}{l}13 \cdot 0 \text { to } 16 \cdot 5 \\
17 \cdot 8 \text { to } 21 \cdot 6\end{array}$ & $\begin{array}{l}5 \cdot 1 \text { to } 6 \cdot 5 \\
7 \cdot 0 \text { to } 8 \cdot 5\end{array}$ & $\overline{-}$ & $\overline{-}$ \\
\hline Nov. 5 & Bigbury Bay & 188 & 13.0 to 16.2 & $5 \cdot 1$ to 6.4 & - & - \\
\hline Nov. 6 & South of Mewstone & $\begin{array}{r}242 \\
26\end{array}$ & $\begin{array}{l}13.0 \text { to } 16.5 \\
20.8 \text { to } 24.5\end{array}$ & $\begin{array}{l}5 \cdot 1 \text { to } 6 \cdot 5 \\
8 \cdot 2 \text { to } 9 \cdot 6\end{array}$ & - & - \\
\hline Nov. 16 & $\begin{array}{l}7 \text { miles south of the } \\
\text { Eddystone }\end{array}$ & 114 & 13.0 to 15.5 & $5 \cdot 1$ to $6 \cdot 1$ & - & - \\
\hline Nov. 17 & $\begin{array}{l}8 \text { miles south-west of } \\
\text { Start Point }\end{array}$ & $\begin{array}{r}49 \\
9\end{array}$ & $\begin{array}{l}13 \cdot 9 \text { to } 15 \cdot 4 \\
21 \cdot 0 \text { to } 23 \cdot 4\end{array}$ & $\begin{array}{l}5 \cdot 5 \text { to } 6 \cdot 0 \\
8 \cdot 2 \text { to } 9 \cdot 2\end{array}$ & - & - \\
\hline Nov. 19 & $\begin{array}{l}10 \text { miles south of } \\
\text { Eddystone }\end{array}$ & $\begin{array}{l}8 \\
4\end{array}$ & $\begin{array}{c}\text { As usual } \\
, "\end{array}$ & - & $\overline{-}$ & - \\
\hline
\end{tabular}




\begin{tabular}{|c|c|c|c|c|c|c|}
\hline \multirow{2}{*}{ Date. } & \multirow{2}{*}{ Locality. } & \multirow{2}{*}{ Number } & \multicolumn{2}{|c|}{ Length. } & \multicolumn{2}{|c|}{ Weight. } \\
\hline & & & Centimetres. & Inches, & Grammes. & Ounces. \\
\hline \multirow{3}{*}{$\begin{array}{c}1891 \\
\text { Nov. } 23\end{array}$} & & & & & & \\
\hline & 3 miles off Rame & 1 & $13 \mathrm{~cm}$ & $5 \cdot 1$ & - & - \\
\hline & Head & 10 & $22 \cdot 1$ to $24 \cdot 1$ & $8 \cdot 7$ to $9 \cdot 5$ & - & - \\
\hline \multirow[t]{3}{*}{ Nov. 24} & West of the Eddy- & 136 & $13^{\circ} 0$ to $16^{\circ}$ & $5 \cdot 1$ to $6 \cdot 5$ & - & - \\
\hline & stone & 6 & 18.4 to $20 \cdot 2$ & $7 \cdot 2$ to $7 \cdot 9$ & 一 & - \\
\hline & & 19 & 21.5 to $25 \cdot 2$ & $8 \cdot 4$ to $9 \cdot 9$ & - & 一 \\
\hline \multirow[t]{2}{*}{ Nov. 27} & 6 miles off Looe & 35 & $12^{\cdot} \cdot 7$ to $15^{\circ} 0$ & $5 \cdot 0$ to $5 \cdot 9$ & - & 一 \\
\hline & & 9 & 20.9 to 22.8 & $8 \cdot 2$ to 8.9 & 一 & - \\
\hline Dec. 15 & Whitsand Bay & 2 & $13 \cdot 9,14: 1$ & 5.5 & 一 & 一 \\
\hline Dec. 16 & $\begin{array}{l}\text { South-east of Mew- } \\
\text { stone }\end{array}$ & $\begin{array}{l}8 \\
3\end{array}$ & $\begin{array}{l}13.5 \text { to } 14.4 \\
22.9 \text { to } 23.7\end{array}$ & $\begin{array}{l}5 \cdot 3 \text { to } 5 \cdot 6 \\
9 \cdot 0 \text { to } 9 \cdot 3\end{array}$ & - & - \\
\hline \multirow[t]{2}{*}{ Dec. 17} & Near Bolt Head & 45 & 13.5 to $15^{\circ} 6$ & $5 \cdot 3$ to $6 \cdot 1$ & - & - \\
\hline & & 18 & Adult & - & - & - \\
\hline \multirow{3}{*}{$\begin{array}{c}\text { Dec. } 22 \\
1892 \\
\text { Jan. } 12\end{array}$} & 10 miles south-east of & 13 & $13 \cdot 8$ to $16 \cdot 2$ & $5 \cdot 4$ to $6 \cdot 4$ & - & - \\
\hline & the Eddystone & 3 & $19 \cdot 2$ to $20 \cdot 3$ & $7 \cdot 5$ to $8 \cdot 0$ & - & 一 \\
\hline & $\begin{array}{l}\text { 14. miles south-south- } \\
\text { east of Plymouth } \\
\text { Sound }\end{array}$ & 2 & $13 \cdot 5,13 \cdot 6$ & $5 \cdot 3$ & - & - \\
\hline
\end{tabular}

As far as I have been able to discover, young pilchards 13 to 16 $\mathrm{cm}$. in length have not been taken in recent years in any considerable numbers on the coast of Devon or Cornwall. There is a factory at Mevagissey where ordinary full-grown pilchards are preserved in oil and tinned in the same manner as French sardines, and Mr. Dunn, who has been for many years connected with this factory, assured me, not only that no such small pilchards had ever been prepared in the factory, but that a deliberate attempt had been made to procure such fish and had not succeeded. A seine of the kind used in the French sardine fishery was obtained from France and several trials made with it, but, instead of half-grown pilchards of the required size, only very young specimens 2 or 3 inches long were captured. Nevertheless it would seem, from the facts here recorded, that small pilchards in all respects similar to the French sardines are to be taken on the English coast.

It will be seen from the table that the young pilchards were most plentiful in November, and scarce in December and January, and that they were taken in considerable numbers in November from the Mewstone to a distance of seven miles south of the Eddystone. If there are any facts or considerations which serve to indicate with more or less probability the age of these young fish, we obtain some light on the question of the rate of growth of the pilchard. In previous papers in this Journal I have shown that the spawning period of the pilchard near Plymouth extends from June to October, but the spawning takes place principally in June, July, August, and September. Therefore the pilchards 13 to $16.5 \mathrm{~cm}$. long in NEW SERIES.-VUL. II, NO. III. 
November must have been either from two to five months old, having been hatched in the summer of the same year, or from fourteen to seventeen months old, having been hatched in the summer of the previous year. It is obvious that the pilchard could not reach a length of $13 \mathrm{~cm}$. in two months, and we have observations on the growth of the young herring, and on the Mediterranean sardine at Marseilles, which show that it could not grow to such a size even in five or six months. Marion's conclusions concerning the sardine at Marseilles are quoted in my paper on the pilchard in the previous number of this Journal; he estimates the length of the year-old fish at $14 \mathrm{~cm}$. I see no reason to suppose that the pilchard at Plymouth grows twice as fast as the sardine at Marseilles. Meyer, after a series of very careful and successful observations, found that the herring in the Baltic at five months old was $6.5 \mathrm{~cm}$. to $7 \cdot 2 \mathrm{~cm}$. long, and we have no reason to think that the pilchard grows twice as fast as the herring. It is nearly certain, therefore, that the pilchards taken at Plymouth in November and measuring 13 to $16.5 \mathrm{~cm}$. in length, were a little more than a year old, being derived from the spawn of the preceding year. But if this be so, where were the young pilchards derived from the spawn shed in the previous summer of the same year?

I had not seen any very young pilchards, that is specimens less than $13 \mathrm{~cm}$. long, since July last when I took the stages described in the previous number of this Journal. At the end of October I was at Mevagissey and discussed the pilchard question with $\mathrm{Mr}$. Dunn. He told me that young pilchards only 2 to 3 inches long were always on the coast between September and Christmas, and that he knew this because he found them at that period in the whiting's' stomachs. He gave me several specimens measuring 5 to $8 \mathrm{~cm}$. in length which he said were taken some years ago in a mackerel seine in September. At Plymouth in November I opened the stomachs of many whiting but found no young pilchards in them. But on opening the stomachs of some mackerel I found the kind of fish for which I was searching. On November 5th I opened twelve mackerel, 10 to 11 inches long, bought on the fishquay; in one of these were two pilchards 6 and $8.5 \mathrm{~cm}$. long which were sufficiently intact to be identified with certainty ; in another was a pilchard $9 \mathrm{~cm}$. long, while in two others were half-digested fish which were probably also young pilchards of similar size. On November 6 th I opened thirty-three mackerel, in seven of which there was food in the stomach, in each case consisting of one or two more or less digested fish 5 to $7 \mathrm{~cm}$. long, apparently pilchards. In one of these mackerel there were remnants of several fish in the condition of poutines nues, and these were certainly clupeoids and probably pilchards. 
It is thus conclusively demonstrated that in November last, when the year-old pilchards were taken in our nets, the mackerel were feeding on younger pilchards 6 to $9 \mathrm{~cm}$. in length $(2 \cdot 3$ to $3 \cdot 5$ inches) which were derived from spawn shed the previous summer.

It seems probable that the pilchards which are 13 to $16 \mathrm{~cm}$. long in November would reach the adult condition at a length of 20 or $22 \mathrm{~cm}$. by the following summer, and would then breed for the first time. I have not yet definitely ascertained that pilchards do breed at the size just mentioned. I measured five ripe females in June, 1891 , and they were from $23 \cdot 7$ to $24.8 \mathrm{~cm}$. long, weighing from 5 to $5 \frac{3}{4}$ oz. But probably if a large number of ripe specimens were measured many would be found to be less than $23 \mathrm{~cm}$. long. I have measured samples of the ordinary adult pilchards taken for the market at various times of the year. For instance, in-

August, 1891, I measured fourteen specimens taken six or seven miles off shore in Whitsand Bay; eleven were females $21 \mathrm{~cm}$. to $25 \cdot 3 \mathrm{~cm}$. long, in all of which the ovaries were small, and in many apparently recently emptied; the other three were males $21 \cdot 3$ and $21 \cdot 4 \mathrm{~cm}$. long.

November 3rd, 1891, I measured six specimens from a large catch taken off Plymouth Sound: they were $21 \mathrm{~cm}$. to $22.5 \mathrm{~cm}$. in length, two females, 4 males; the generative organs in all very small.

The largest pilchard I have seen was brought to me in December, 1890 , and measured $27 \frac{1}{2} \mathrm{~cm} .=11$ inches in length; it weighed $8 \frac{1}{2}$ oz., and its generative organs were extremely small and rudimentary, as though it had become sterile from old age.

In my preceding paper on the pilchard in this Journal, and in an article in Nature, January 14, 1892, I have referred to Professor Pouchet's Reports on observations on the sardine made at Concarneau on the coast of Brittany. I propose here to give a more extensive account and criticism of Pouchet's records, comparing them with those I have made at Plymouth, in order to see if they confirm, supplement, or modify the conclusions I have suggested above as to the rate of growth. The records in question date from the year 1887, only a few scattered observations having been made before that time. I will give here a list of the publications in which these records are contained:

(1) Rapport sur le Fonctionnement du Laboratoire de Concarneau en 1887 et sur la Sardine, par M. G. Pouchet. Ministère de l'Instruction publique et des Beaux-Arts. Paris, Imprimerie Nationale, 1888.

(2) Le Régime de la Sardine sur la Côte Océanique de France en 1887, par M. G. Pouchet. Comptes Rendus, 20 February, 1888. 
(3) Rapport sur le Laboratoire de Concarneau en 1888 et sur la Sardine, Journ. de l'Anat et de la Phys., 1889.

(4) Sur la Croissance de la Sardine océanique, Comptes Rendus, 29 July, 1889. Tome cix, No. 3.

(5) La Question de la Sardine, Revue Scientifique, 11 Juin, 1887.

(6) Le Régime de la Sardine, Revue Scientifique, 24 Août, 1889.

(7) Rapport sur le Laboratoire de Concarneau en 1889 et sur la Sardine, Journ. de l'Anat. et de la Phys., 1890.

(8) Nouvelles observations sur la Sardine océanique, Comptes Rendus, 7 Avril, 1891. Tome cxii.

In the first document in this list (1) we find in the general report the following argument:

Admitting that the sardine de dérive (i.e. the full-grown sardine, which is in all respects the same as the English pilchard), which is fished at the end of winter, is sometimes almost ready to spawn, it is impossible to admit that the sardine de rogue, which is taken during the following six or seven months, is derived from the spawning of these large sardines in the same year. Judging from the data furnished by Coste and others concerning the growth of the salmon and trout, and by H. A. Meyer as to the growth of the herring, we may in all probability attribute to the sardine an increase of 1 centimetre per month. Thus, the ordinary sardine de rogue, 10 to 12 centimetres long, would be about one year old.

Annexe $\mathrm{E}$ of this same report contains a tabular record of the results of the examination of sardines at Concarneau from May 8th to October 23rd, 1887. In this appendix no information is given concerning the limits of size or the general character of the whole catch for any particular day; each entry consists merely of the dimensions and other particulars of one or a few specimens examined at a certain date. From the 8 th to the 26th of May inclusive, seventeen fish were examined; these were from $17 \cdot 6$ to $22.5 \mathrm{~cm}$. in length; with the exception of one, the smallest, these were all adult sardines, and in some of them the generative organs were approaching maturity. The sardine de rogue had not yet made its appearance. On May 27th a specimen was $16.0 \mathrm{~cm}$. long. In June four specimens are recorded, 14.8 to $16.8 \mathrm{~cm}$. long, weighing from 25 to 42 grammes. In July fourteen specimens examined; two of these were adult, 18.2 to $20.5 \mathrm{~cm}$. long; the rest were from 12.0 to $17 \cdot 9 \mathrm{~cm}$. On the 6 th and 29 th of August two very small specimens are recorded, measuring only 9.8 and about $10.5 \mathrm{~cm}$.; the other nine examined this month were from 12:0 to $15 \cdot 1 \mathrm{~cm}$. Even the smallest of these, $9 \cdot 8 \mathrm{~cm}$. long, was probably too large to be derived from the same year's spawning, and represents the spawn shed late the preceding year. In September sixteen specimens 
were examined ; the lengths, when given, are from 13.5 to $17.0 \mathrm{~cm}$., the weight from 9 grammes to 46 grammes. In October, of eighteen specimens examined two were adult, measuring 19.5 and $19.8 \mathrm{~cm}$., of the rest the lengths are rarely given, but the weights are from 15 to 58 grams.

If we exclude from the above records the fish which I have specified as adult, and which are probably two years old, and also bear in mind that the spawning period of the pilchard extends from the end of May to the beginning of November at Concarneau, doubtless as at Plymouth, I think we may fairly conclude that the French sardine de rogue, measuring from 12 to $17 \mathrm{~cm}$. in length, is the product of the previous year's spawning, and is about one year old.

In Appendix D of the same report, where a résumé of observations on the year's fishing is given by M. Bovier-Lapierre, the size of the fish being indicated only by weight, it is stated that the year 1887 was remarkable, firstly for the abundance of the fish, secondly for the constant mixture of fish of different sizes, thirdly for the small size of part of the fish.

In the paper (2) published in the Comptes Rendus a fact is mentioned which is not sufficiently indicated in the Report, namely, the appearance in great numbers at the commencement of June of sardines too small for the market, and weighing only three or four grammes. The length of these is unfortunately not stated, but can be calculated at 7 or $8 \mathrm{~cm}$., so that these also were too large to be derived from the same year's spawning, and would seem to indicate merely a late spawning of the previous year.

The article in the Revue Scientifique, No. 5, in the list of Pouchet's papers contains nothing bearing upon the growth of the sardine beyond what I have noticed in the other two papers.

In the Report for 1888 (No. 3 in the list) we have voluminous documents on the sardine. As in the preceding Report we have actual measurements and details of a few sardines examined at short intervals during the season. The drift fishing was continued till May 29th, and was then succeeded by the fishing $\grave{a}$ la rogue, that is with cod-roe bait. The individuals examined at the Laboratory in April and May were nine in number; three of these were adult, 19.0 to $19.5 \mathrm{~cm}$. in length (that is to say, were the sardines de rogue of the preceding year, and now nearly two years old). The rest were 10.7 to $14.0 \mathrm{~cm}$. long, evidently the produce of the previous summer's spawning. In May measurements of several adult individuals are given (sardines de dérive), but there are also a few sardines de rogue measuring about $15 \cdot 0 \mathrm{~cm}$. The records for the rest of the summer are similar to those of the preceding year, the sardines de rogue varying from 14 to 16 or $17 \mathrm{~cm}$. The general 
characters of the fishery for the summer season are thus described: the fish appeared first at the south at Sables d'Olonne (May 9th), and then progressively at more northern centres, arriving at Douarnenez on June 10th. Similarly, the fishery terminated first in the south on October 10th, continuing in the north a month later. The dimensions of the fish were remarkably uniform, the diminution in size usually observed about July not having occurred in 1888. On the other hand, a slight increase in the average size, quite sensible and general, was observable from the commencement to the termination of the fishery. A peculiarity of the year was the absence of fish from the 1st to the 20th of July. Pouchet points out that the observations on individual sardines made in the Laboratory prove that the sardine de rogue is a young fish which has never spawned, nearly mature ovaries being found only in the sardine de dérive. He adds that unfortunately the incessant displacement of the sardine de rogue, and its final disappearance in autumn, deprive us of the principal elements necessary to approach the interesting problem of its rate of growth, and of the age of those which visit the French coast in summer. With this opinion I am unable to agree; it seems to me that although we cannot actually observe the increase in size in given individuals, or even a given shoal, yet since we know pretty accurately the extent of the spawning period, we can judge with sufficient certainty from which spawning season fish of a particular size taken at a particular period of the year are derived.

Neither in the Report for 1888 nor in that for 1887 are there any actual observations as to the range of size of the fish caught on particular days throughout the season, but only, as I have already mentioned, measurements of two or three specimens made several times a month. There is not even anything to indicate whether the individual fish selected represented the minimum, maximum, or average size of the fish caught. In this Report for 1888 a substitute is presented for the data to the absence of which I refer, namely, the records obtained by a sardine-curer of the average size of the fish used in each week, expressed by the number of fish required to fill a box of a certain size known in the trade as the boîte d'un quart, and measuring $12 \times 10 \times 2 \mathrm{~cm}$. These records extend over several years, and include several different fishing stations. In these tables the highest figures represent the smallest fish, because of course the smaller the fish the larger the number required to fill a box whose size is fixed. The actual size represented by the figures is not easy to ascertain with any certainty, but some approximation to it may be made by means of relations given by Pouchet.*

\footnotetext{
* Thus the weight of fish in a box is 123 grammes; this amount of fish when fresh
} 
The character of the fishery, what Pouchet calls the régime, varies to a certain degree from year to year; but in the several places named, such as Quiberon, Kernevel, Concarneau, Douarnenez, there is considerable similarity in the same year. The size of the fish taken in different years at the same month varies, but usually the number to the box is ten to fourteen in July, and seven to eight in October. But the fishing begins in June, or the end of May, and the fish taken in these months is usually larger than that taken in July, giving only seven to nine to the box. The smaller fish which usually appears in July is called the poisson de Juillet. In some years the diminution in July is not observable, the fish gradually increasing in size from the beginning to the end of the season, and appearing to grow in size on the fishing ground. In other years again, for instance in 1887, extremely small fish, twenty to twenty-six to the box, made their appearance in September and October on the whole coast, with the exception of the Bay of Douarnenez, into which they did not penetrate.

I reproduce here the table of relations between the number of fish to the box and the weight of the single fish, as given by Pouchet, with an additional column showing approximately the corresponding length of the fish.

\begin{tabular}{|c|c|c|c|c|c|c|}
\hline $\begin{array}{l}\text { Number of sardines } \\
\text { to the quarter box. }\end{array}$ & & $\begin{array}{l}\text { Wei } \\
\text { each }\end{array}$ & $\begin{array}{l}\text { at of } \\
\text { rdine. }\end{array}$ & & $\begin{array}{l}\text { Corresp } \\
\text { length of }\end{array}$ & $\begin{array}{l}\text { onding } \\
\text { sardine }\end{array}$ \\
\hline $33-35$ & $\ldots$ & $7 \cdot 3 \mathrm{~g}$ & ams. & $\ldots$ & $10 \cdot 0$ & $\mathrm{~cm}$. \\
\hline $28-30$ & $\ldots$ & $8 \cdot 6$ & , & $\ldots$ & 10.5 & , \\
\hline $24-25$ & $\ldots$ & $10 \cdot 2$ & , & $\ldots$ & $11 \cdot 3$ & , \\
\hline 20 & $\ldots$ & $12 \cdot 5$ & , & $\ldots$ & 11.5 & ", \\
\hline 18 & $\ldots$ & $13 \cdot 8$ & ", & $\ldots$ & $12 \cdot 0$ & , \\
\hline 16 & $\ldots$ & $15 \cdot 6$ & , & $\ldots$ & $12 \cdot 5$ & , \\
\hline 15 & $\ldots$ & $16 \cdot 6$ & ", & $\ldots$ & $12 \cdot 8$ & , \\
\hline 14 & $\ldots$ & $17 \cdot 2$ & , & $\ldots$ & $13 \cdot 0$ & , \\
\hline 13 & $\ldots$ & $19 \cdot 2$ & , & $\ldots$ & $13 \cdot 4$ & ” \\
\hline 12 & $\ldots$ & $20 \cdot 8$ & , & $\ldots$ & $13 \cdot 7$ & , \\
\hline 11 & $\ldots$ & $22 \cdot 7$ & ” & $\ldots$ & $14 \cdot 0$ & ", \\
\hline 10 & $\ldots$ & $25 \cdot 0$ & ", & $\ldots$ & $14: 5$ & " \\
\hline 9 & $\ldots$ & $27 \cdot 7$ & , & $\ldots$ & $15 \cdot 0$ & " \\
\hline 8 & $\ldots$ & $31 \cdot 2$ & , & $\ldots$ & $15 \cdot 5$ & ” \\
\hline 7 & $\ldots$ & $35 \cdot 7$ & , & $\ldots$ & $16 \cdot 2$ & , \\
\hline 6 & $\ldots$ & $41 \cdot 6$ & " & $\ldots$ & $17 \cdot 0$ & ", \\
\hline 3 & $\ldots$ & $83 \cdot 3$ & " & $\ldots$ & $21 \cdot 4$ & , \\
\hline
\end{tabular}

With these relations may be compared the actual lengths and would weigh twice as much, or 250 grammes nearly. Therefore if we divide 250 by the number of fish to a box we get the average weight of a single fresh fish. For instance, 12 to a box means fish each of which weighs 20.8 grammes. Again, Pouchet gives a curve of the relation between the weight and length of the sardine based upon actual observations, and from this we find that a weight of 20.8 grammes correspond to a length of about $13.6 \mathrm{~cm}$, a result which agrees with my own observations. 
weights ascertained by myself from the specimens taken at Plymouth on November 3rd, 1891.

\begin{tabular}{|c|c|c|c|c|c|c|c|}
\hline \multicolumn{2}{|c|}{14.25 grms. } & ... & $13.0 \mathrm{~cm}$. & 30.55 & ms. & $\ldots$ & $16.2 \mathrm{~cm}$. \\
\hline $17 \cdot 65$ & $"$ & $\cdots$ & $13 \cdot 7$, & $59 \cdot 60$ & " & $\ldots$ & $18 \cdot 6$, \\
\hline $21 \cdot 80$ & , & $\ldots$ & $14 \cdot 3$, & $55 \cdot 50$ & , & $\ldots$ & $19 \cdot 0$, \\
\hline $23 \cdot 50$ & , & $\ldots$ & $15 \cdot 0$, & $74: 70$ & , & $\ldots$ & $19 \cdot 4$, \\
\hline 30.95 & , & $\ldots$ & $15 \cdot 8$, & $69 \cdot 40$ & ” & ... & $19 \cdot 7$, \\
\hline $32 \cdot 70$ & " & $\ldots$ & $16^{\circ} 0$ & $84: 40$ & " & ... & $21 \cdot 4$ \\
\hline $34 \cdot 15$ & , & $\ldots$ & $16 \cdot 1$, & $84: 85$ & $"$ & ... & $21 \cdot 8$, \\
\hline
\end{tabular}

It will be seen that the differences between the proportions observed by me, and those taken from Pouchet, are not very great, the lengths in the latter being a little too small in proportion to the weight. However, we may take the lengths of the fish corresponding to the number to a box, as given above, to be approximately correct, and interpreting the annual records in Pouchet's reports by their means, we may try to discover what are the biological facts underlying the industrial statistics.

But before offering my own interpretations and criticisms, I must quote those of Pouchet himself, who derotes a special short appendix in the Report for 1888 (Annexe D) to the subject of the growth and the age of the sardine. Pouchet regards this question, as he regards all others concerning the life history of the sardine, from the most sceptical point of view possible, insisting that no calculation, without the observation regularly followed of the same individuals, can give us exact information concerning the growth of any species of animal, as the growth, whether in weight or length, may describe the most irregular curves. He refers to what he said in the previous Report, for 1887 as to the probability that the sardine de rogue is about one year old, that it has never spawned, and that from October onwards it begins to show indications of the development of the genital organs. He then discusses the apparent increase in size of the fish in the same locality, as shown by the industrial records. This gradual increase presents itself more frequently in the Bay of Douarnenez as though the fish which entered the bay remained there and grew ; but, on the other hand, sudden changes of size show that the fish even there very often depart and give place to new shoals. Pouchet takes the records of the years in which this gradual increase was most regular, and translating the figures into weight and lengths of individual fish, compares the results with one another, with the following results :

DodaRnknez, 1888.

15 to box to 9 to box.

$16 \cdot 6$ grms. to 27 grms. $=11$ grms.

$12.5 \mathrm{~cm}$. to $14.8 \mathrm{~cm},=2 \cdot 3 \mathrm{~cm}$,

15th August to 10th October. 56 days. 
Belle-IsLe, 1888.

15 to box to 8 to box.

$\left.\begin{array}{l}15 \text { to box to } 8 \text { to box. } \\ 16.6 \text { grms. to } 30 \text { grms. }=14 \text { grms. } \\ 12.5 \mathrm{~cm} \text {. to } 15.0 \mathrm{~cm} .=2.5 \mathrm{~cm} .\end{array}\right\} \begin{gathered}10 \text { th September to } 30 \text { th November. } \\ 81 \text { days. }\end{gathered}$

Le Croisic, 1888.

12 to box to 9 to box.

20 grms. to 27 grms. $=7$ grms.

$14.0 \mathrm{~cm}$. to $14.5 \mathrm{~cm} .=0.5 \mathrm{~cm}$.

15th August to 15th October.

61 days.

QUIBERON, 1884.

12 to box to 6 to box.

22 grms. to 40 grms. $=18$ grms.

$13 \cdot 0 \mathrm{~cm}$. to $17 \cdot 7 \mathrm{~cm} .=4 \cdot 7 \mathrm{~cm}$.

15th June to 21st September.

98 days.

KeRneVel, 1869.

12 to box to 7 to box.

20 grms. to 34 grms,$=14$ grms.

$14.0 \mathrm{~cm}$. to $16.5 \mathrm{~cm} .=2.5 \mathrm{~cm}$.

These are sufficient to show the irregularity of the results obtained in this way. I have copied the figures as given by Pouchet. Pouchet thinks that the growth of a pelagic species like the pilchard ought to be very uniform, because they inhabit water of uniform temperature, and their microscopic food is always sufficient. He thinks that the inequality of the above results must be due either to the character of the records from which they are derived, or to the fact that the differences of size in the records represent displacements of the fish and not the growth of stationary fish. There is doubtless much reason for this judgement, but I am sorry to be obliged to point out that the calculation of these results offered as samples is marred with serious errors. Thus, the period chosen at Belle Isle for 1888 is 10 th September to 30 th November, and it is said that the record for the latter day is eight fish to the box, whereas the table for 1888, from which the figures are taken, ends at November 14th, and gives no figures for November 30th, the figure 8 occurring on October 27th.

The figure 12 as the number per box at two places is translated into weight 20 grms., length $14.0 \mathrm{~cm}$.; at another into weight 22 grms., length $13.0 \mathrm{~cm}$., as though the length of the fish decreased as the weight increased. The lengths given as corresponding to the weights do not agree with the graphic on another page of the report.

Pouchet's industrial records occasionally show two features which are worthy of attention, namely, the appearance of smaller fish in July, and the appearance of still smaller specimens in September and October. This 'poisson de Juillet' is represented by the figures 11 to 13 , so that its size is 13.4 to $14.0 \mathrm{~cm}$., and its weight $19 \cdot 2$ to $22 \cdot 7$ grms. Its occurrence is indicated by Pouchet in the 
years $1873,1874,1875,1876$, and a trace of it in 1878 , that is in five years only out of twenty-five of which he gives the "régime." In the years in which it occurred the fish caught in June were 15 to $17 \mathrm{~cm}$. long. But in many years, in which the diminution in July is not observable, the fish caught in June are no larger than the poisson de Juillet; for instance, in 1877, 1878, 1879, 1883, 1884. Such facts as these, it seems to me, are not surprising when we consider that the pilchard has a spawning period of five or six months, and that its movements are probably not regular. Probably fish 15 or $16 \mathrm{~cm}$. long, caught in June, are fish hatched unusually early in the preceding season, while those of 13 to $14 \mathrm{~cm}$. are produced from a later spawning. In some years the fish are throughout the season of unusually small size, and this may be due to a scarcity of food in the preceding winter. The very small fish occurring in 1887 in September and October were 11.0 to $11.5 \mathrm{~cm}$. long, and probably were derived from eggs shed the preceding May and June, having grown unusually fast.

I quite agree with Pouchet that it is impossible to obtain from the industrial records satisfactory evidence of the actual increase in size of the sardine from the beginning to the end of the fishing season. The data we have to deal with, even when the calculations are arithmetically correct, as Pouchet's are not, are such distant approximations, and it is so evident that in most cases we are not comparing the average sizes of the same shoals, that no great importance can be attached to the difference in size shown between the fish in different months. All that can be said is that usually a difference of 2.5 to $3.5 \mathrm{~cm}$. in length is the result of comparing the sizes of the fish given for July and October.

The subject of the nets used in the French fishery deserves some mention. Unfortunately Professor Pouchet does not give a complete account of them; but he states in one place that the mesh is measured by the length occupied by five knots, that is a length equal to four times the side of one mesh, and I find from the figures he gives that the mesh of the nets used varies from $\frac{4}{10}$ ths to $\frac{6}{10}$ ths of an inch. I gather that the nets here referred to are drift nets used with the bait or rogue, for it is stated that the fishermen change their nets to suit the varying size of the fish, which they would not need to do if they were using a suitable seine. Thus, some of the nets used in the French fishery have the same mesh as those we have been using at Plymouth. It must be remembered that Professor Pouchet only refers to the fish caught by the fishermen; he denies that there are ever any still smaller fish a few weeks or months old in the waters where the fishery is carried on, but as the nets used could not catch these smaller fish of 3 to 7 or 
$8 \mathrm{~cm}$. in length the absence of the latter is of course not proved. Seines are also used in the French fishery, but not generally, and their introduction has given rise to a great deal of agitation, the majority of the fishermen with their usual conservatism asserting that the greater efficiency of the seines, which secure very large catches, upsets the regular working of the industrial organisation, and will lead to the extermination of the sardine.

In Pouchet's Report for 1889 we have the régime of the sardine de rogue for that year exhibited and discussed in the usual manner. The table of the season appears to be taken, like that for 1888, from the trade journal published at Nantes, and gives the average number of the fish per box for every day of the season. In the Report it is pointed out that the constant phenomena evident in this, as in all seasons, are-1st, that the fish is always smaller at the south of the fishing area, namely, towards Sables d'Olonne, than in the north towards Concarneau; 2nd, that the fishing begins first in the south and extends progressively towards the northern stations, and ceases in the same order. Thus, the fishing commenced at Sables on May 3rd at Douarnenez on June 15th, was over at Sables on the 15th September, and on the coast of Finisterre continued till the 15th November.

The peculiar features of the season were the following :- $\mathrm{Up}$ to the 15th August the fish continued of the same dimensions, then on the coast of Finisterre very small fish came in, which might be regarded as the poisson de Juillet, appearing some weeks later than usual. These fish showed themselves from the south to the north progressively. If we look at the figures for Concarneau we find the size of the fish in July was 8 to 10 , that is 14.5 to $15.5 \mathrm{~cm}$. long, 25 to 31 grammes in weight. The small fish were taken only on three or four days in August, and were 26 to 30 to the box, that is about 8.6 grammes in weight, and $10.5 \mathrm{~cm}$. long. Small as these seem to have been, and difficult as it is to judge of their real size by such an unsatisfactory method, it seems to me that they must have been derived from a late spawning of the previous year.

In this same Report Pouchet gives a complete record of his observations on the condition of the generative organs in the adult sardines, the chief result of which is that he found mature eggs only in specimens over $19 \mathrm{~cm}$. in length, and only in April, 1890, and May, 1888.

In my endeavours above to deduce the age of the sardines de rogue, whose sizes are recorded by Pouchet, I have assumed that the spawning period at Concarneau is practically the same as at Plymouth. Pouchet's observations show that some pilchards spawn at Concarneau in April ; but they give no indication of summer or 
autumn spawning. At Plymouth I have evidence that spawning goes on in every month from June to November inclusive; it may be that some pilchards spawn both at Concarneau and at Plymouth also in April and May, or it may be that spawning commences earlier in the Bay of Biscay than further north in the English Channel, or it may be that the individuals found to contain some mature ova by Pouchet, would not have actually spawned till near the end of May. In any case, we have at present no indication that there are two spawning periods, or more than one maximum and minimum of spawning activity in the species.

In the note in the Comptes Rendus of April, 1891, Pouchet merely summarises the results of the observations in his last report, which I have already reviewed. After studying the researches continued for several years at Concarneau, we cannot help being surprised that so much careful and systematic work should have contributed so little to the elucidation of the life-history of the sardine. The reasons for this failure are, it seems to me, of two kinds :- 1 st, the adoption by Professor Pouchet of preconceived ideas concerning the mode of life of the species, and the relation between this mode of life and the sardine fishery; $2 \mathrm{nd}$, the employment of inadequate and unsuitable methods, and want of experience in the investigation of the history of marine fishes in general. I cannot help thinking that results of greater value would have been obtained if the actual weights and measurements had been ascertained in the Laboratory of large samples of the fish caught, if the régime of the fishery had been expressed in scientific rather than industrial terms. It seems also probable that if pelagic collecting had been carried on with sufficient frequency and suitable instruments in the summer off the French coast, the eggs and alevins of the pilchard would have been obtained in abundance in all stages.

However this may be, it is very desirable that the number and character of young pilchards occurring in the neighbourhood of Plymouth throughout the year should be ascertained, and for this purpose I have suggested that our small-meshed nets should be shot three or four times every month during the present season. It would be still better if we had a fleet of nets of various different meshes, so as to take fish of various sizes.

The position and extent of the region where the French sardine fishery and preserving industry are carried on are indicated in the map appended to this paper, in which the situation of all the localities mentioned can be seen at a glance. 


\section{Engraulis encrasicholus, the Anchovy.}

The Dutch ichthyologist, C. K. Hoffmann,* when investigating the anchovy in the Zuyder Zee, captured a number of the young of this species at short intervals in August, September, and October. Their numbers and sizes were as follows:

\begin{tabular}{|c|c|c|c|c|c|c|c|c|c|c|c|}
\hline $\begin{array}{l}\text { Date. } \\
\text { Aug. } 4\end{array}$ & $\ldots$ & $\begin{array}{c}\text { Number } \\
10\end{array}$ & r. & $\begin{array}{l}\text { Length. } \\
4 \cdot 2-5 \cdot 2 \mathrm{c}\end{array}$ & $\mathrm{cm}$. & $\begin{array}{c}\text { Date. } \\
\text { Sept. } 4\end{array}$ & $\ldots$ & $\begin{array}{c}\text { Num } \\
6\end{array}$ & $\begin{array}{l}\text { ber. } \\
\ldots\end{array}$ & $\begin{array}{l}\text { Length. } \\
7 \cdot 0-10 \cdot 0\end{array}$ & cm. \\
\hline , 8 & $\ldots$ & 9 & $\ldots$ & $3 \cdot 2-5 \cdot 5$ & ", & 5 & $\cdots$ & 5 & $\ldots$ & $5 \cdot 0-7 \cdot 0$ & ", \\
\hline, 10 & $\ldots$ & 10 & $\ldots$ & $4.5-6.5$ & , & , & $\ldots$ & 8 & $\ldots$ & $5 \cdot 5-7 \cdot 5$ & " \\
\hline , 12 & $\ldots$ & 9 & $\ldots$ & $4 \cdot 5-6 \cdot 5$ & $"$ & , & $\ldots$ & 9 & $\ldots$ & $6 \cdot 0-7 \cdot 5$ & " \\
\hline, 14 & $\ldots$ & 9 & $\ldots$ & $3 \cdot 8-7 \cdot 2$ & ", & , 10 & $\cdots$ & 7 & $\ldots$ & $6 \cdot 0-8 \cdot 5$ & ", \\
\hline , 19 & $\ldots$ & 6 & $\cdots$ & $5 \cdot 5-7 \cdot 0$ & , & , 22 & $\ldots$ & 5 & $\ldots$ & $8 \cdot 0-9 \cdot 5$ & , \\
\hline , 20 & $\ldots$ & 8 & $\ldots$ & $6 \cdot 0-7 \cdot 5$ & $"$ & , 24 & $\cdots$ & 6 & $\ldots$ & $7 \cdot 0-9 \cdot 5$ & " \\
\hline , 22 & $\ldots$ & 7 & ... & $6 \cdot 0-8 \cdot 0$ & " & \# 26 & ... & 6 & $\ldots$ & $9 \cdot 0-9 \cdot 5$ & " \\
\hline , 24 & $\ldots$ & 10 & ... & $3 \cdot 5-6 \cdot 0$ & , & Oct. 9 & $\cdots$ & 8 & $\ldots$ & $7 \cdot 0-9 \cdot 0$ & , \\
\hline , 25 & $\ldots$ & 7 & $\ldots$ & $5 \cdot 5-7 \cdot 0$ & " & , 12 & $\ldots$ & 5 & $\ldots$ & $9.5-10.5$ & , \\
\hline , 26 & $\ldots$ & 6 & $\ldots$ & $4.5-6.5$ & " & , 14 & ... & 6 & $\ldots$ & $8 \cdot 5-11 \cdot 0$ & " \\
\hline 27 & $\ldots$ & 6 & $\ldots$ & $5 \cdot 5-8 \cdot 0$ & " & , 17 & $\ldots$ & 8 & $\ldots$ & $8.5-11.5$ & , \\
\hline 28 & $\cdots$ & 6 & $\ldots$ & $6 \cdot 2-8 \cdot 0$ & , & End & $\ldots$ & 6 & $\ldots$ & $10 \cdot 0-12.0$ & ", \\
\hline
\end{tabular}

Hoffmann proceeds to state that the average length of the sexually mature spawning anchovy is $15 \mathrm{~cm}$., but ripe specimens of only 13.0 to $13.5 \mathrm{~cm}$. are not altogether rare. The conclusion which he draws from his observations, and which he emphasises by means of italics, is the following:- "The anchovy comes in shoals into the Zuyder Zee in order to spawn; those which are not captured depart after spawning, except a few which remain behind. The young brood remain during the first months of their life in the Zuyder Zee ; they grow very fast, and at the end of October have already reached a length of $12 \mathrm{~cm}$; then, and not till then, the young depart."

At the time when Hoffmann formed this conclusion the larval stage of the anchovy was unknown, and the fertilised eggs had not been seen. But Hoffmann had himself observed that the anchovies in the Zuyder Zee were sexually ripe in the latter half of June and in July. In the last week of July all the anchovies he obtained had just shed their spawn. He argues that temperature has a very great influence, not merely on the time of development of the eggs of fishes, but on their rate of growth, and that the anchovy grows very fast on account of the high summer temperature of the water of the Zuyder Zee. He refers to Meyer's result concerning the spring herring in the Baltic, namely, that the young hatched in April and May reach a length of 3.5 to $4.2 \mathrm{~cm}$. in two or three months.

* Bijdrage tot de kennis der levenswjze en der voortplanting van de ansjovis, Verslag van den Staat der Nederlandsche Zeevisscherijen over 1885, Bijlage ii. 
Ehrenbaum,* in a paper just published, has criticised Hoffmann's observations and conclusions, and shows that it is much more probable that the young anchovies examined and measured by the latter were in their second year. In this opinion I entirely agree with Ehrenbaum. We know now, from the researches of Wenckebach and others, carried out subsequently to Hoffmann's, that the anchovy spawns in the Zuyder Zee only in .June and July, and we know that the herring does not commence its metamorphosis until it is two months old, when it is 3.4 to $3.6 \mathrm{~cm}$. long. Without very clear evidence to the contrary, which Hoffmann did not obtain, we must suppose that the anchovy would commence its metamorphosis at the same age and a much smaller size, seeing that the adult anchovy is only about half the size of the herring. The anchovy larvæ of the year in the Zuyder Zee at the beginning of August would be only two to eight weeks old, and therefore still in the larval state, without scales, the oldest having a length of about $2 \cdot 0 \mathrm{~cm}$. Therefore, even the smallest of the specimens recorded by Hoffmann must have been a year old. According to Hoffmann's view the anchovy would reach in about four months the same length as the herring takes ten months to attain to, although the herring is so much the larger fish. Hoffmann's observations prove in fact conclusively the very opposite of the proposition he maintains, namely, that just after the spawning time of the anchovy, year-old specimens are obtained, which are incapable of reproduction, and even at the end of the following October these anchovies are smaller than the smallest mature individuals. Hence it is clear that the anchovy breeds for the first time like the herring and sprat and the flat-fishes, when it is two years old.

In 1890 a Report on the Zuyder Zee Fishery by Dr. P. P. C. Hoek was published by the Dutch Collegie voor de Zeevisscherijen, and a chapter of this Report is devoted to the fishes of the Zuyder Zee. This chapter, with slight modifications, was also published in English in the Tijdschrift der Nederlandsche Dierlundige Vereeniging for 1890. Somewhat to my surprise I find that Dr. Hoek accepts Hoffmann's conclusions concerning the growth of the anchovy. Hoek's observations were as follows:-On July 6th he took an anchovy larva of about $1.5 \mathrm{~cm}$. in length. He does not say how the larva was identified, merely referring to its characteristic shape. The larva is evidently still without scales, at the stage when the permanent dorsal, caudal, and ventral (or anal) fins have recently been defined, and the primordial fin-membrane has disappeared. It is difficult to judge from the figure whether the permanent fin-rays have appeared,

* Die Sardelle (Engraulis encrasicholus, L.), Mittheilungen der Sektion für Küsten und Hochseefischerei der deutschen Fischerei Vereins, Jahrgang 1892. 
or the temporary finer rays still remain. The figure shows the specimen in a somewhat shrunken condition. The stage of this specimen is somewhat earlier than that of the pilchard larva figured by me in Plate X, vol. ii, Part 2 of this Journal. This anchovy larva must have been not more than one month old, having been hatched in June. On September 19th Hoek obtained some small anchovies measuring 6.2 to $8.5 \mathrm{~cm}$, , and estimates their age at two and a half to three months, an age at which the herring measures 4.5 to $5.0 \mathrm{~cm}$.

Hoffmann has also described specimens believed by him to be larvæ of the anchovy.* His identification was based on the fact that the number of the vertebræ was forty-eight. Günther gives the vertebræ in the sprat as forty-seven to forty-nine. Möbius and Heincke forty-six to fifty; the latter authors give the number in the anchovy as forty-six to forty-eight. Matthews found the number in the sprat to be forty-eight. But Hoffmann says he found always forty-nine to fifty vertebræ in the sprat in the Zuyder Zee, and forty-eight in the anchovy. The clupeoid larvæ he took were captured on July 27 th to 31 st, and varied in length from 16 to $30 \mathrm{~mm}$. The smaller of these might easily have been anchovies hatched in June; that the largest were anchovies in much more doubtful; but even if they were, it would by no means prove that young anchovies hatched in June could reach a length of $8.0 \mathrm{~cm}$. in August.

Reference has previously been made in this Journal† to Hoffmann's theory concerning the relation between the summer temperature of the air in the region of the Zuyder Zee and the variations in the annual catch of anchovies from that body of water. The theory is that an unusually warm summer in one year is followed by an unusually large catch of anchovies in the following year. The explanation of the supposed sequence is that the warm summer means a very abundant production of eggs and young larvæ of the anchovy ; the high temperature ensures an abundance of food for the young fish, and also favours their healthy development and growth. The young thus survive in unusual abundance, to depart for the open sea in autumn and return in the following summer, and give rise to a successful fishery. It may be suspected that the theory itself owed its origin partly to Hoffmann's mistaken belief that the anchovy reached its adult size and condition in one year. That belief having been proved to be unfounded, some other explanation of the connection between summer temperature and fishery must be sought, supposing the connection really to exist. Ehrenbaum remarks that the theory is equally consistent with his own view that the young

* Verslag Nederlandsche Zeevisschereien over 1886, Bijlage iv.

† Vol. i, N. S., p. 334 . 
anchovies observed by Hoffmann were in their second year. This is to some extent true, for if we suppose that in a cold summer many of the yearling fish would be starved or killed by the cold, of course fewer would survive until the fishery of the following summer, when they would reach the adult condition. But in this case the temperature of the summer two years before the fishery would also have a great influence, since the fish would then be hatched and reared, and Hoffmann's theory only refers to the immediately preceding year. Ehrenbaum mentions that Dr. Hoek has come to conclusions unfavourable to Hoffmann's theory, having found that the exceptions to it are very numerous. In fact, if we examine Hoffmann's records we find that though the years in which the fishery has been unusually productive have always been preceded by an unusually warm summer, the unusually warm summers have by no means always been followed by an abundance of anchovies. For instance, in the years 1861 and 1884 there was no great difference in the summer temperature; both were above the mean, while in 1862 the catch was 9,413 ankers, and in 1885 104,275 ankers. In 1883 the temperature was much below the average, and in the following year the catch was 30,318 ankers. If we compare the magnitude of the catch with the temperature in the same summer we find that a high temperature is usually accompanied by a small catch, and a low temperature by a large catch, and this rule seems to have as few exceptions as Hoffmann's. On the whole, it seems clear that the conditions which determine the number of anchovies which enter the Zuyder Zee are more complicated than Hoffmann's theory supposes, and that much labour and ingenuity will still be required before their exact nature and influence are ascertained.

Clupea alosa and C. finta, the Shads.

My attention was directed to the rate of growth of the anchovy and the shads by the perusal of Ehrenbaum's paper on the anchovy, to which I have already referred. With regard to the anchovy, I am in complete agreement with him; but he seems to me, in correcting Hoffmann as to the growth of that species, to have fallen into an equal error in the opposite direction with regard to the shad. $\mathrm{He}$ says there is one clupeoid, namely, Alosa vulgaris and finta (why he calls these two, one, I do not know), which, according to Metzger and Hoek, grows about as fast as the anchovy according to Hoffmann. Metzger supposes that the shads hatched at the end of May reach in the first autumn a length of 6.0 to $10.0 \mathrm{~cm}$. Hoek found at the end of July young shads which were $4.5 \mathrm{~cm}$. long. Ehrenbaum 
himself has taken in the Elbe young shad of the following dimensions :

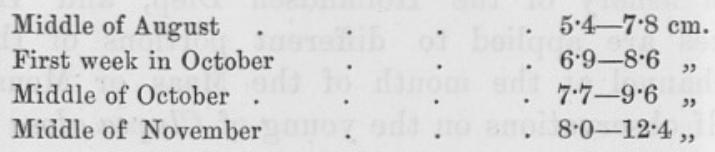

Ehrenbaum calls these specimens Finten, so that I suppose they were identified as Clupea finta. He says that Hoek has recently altered his former opinion, and now concludes that these young specimens, which have already reached the permanent form, that is, have finished their metamorphosis at the end of July, cannot be derived from the spawn of the same year, but are already a year old, and Ehrenbaum agrees with him. He goes on to state that in the summer of 1891 he observed the spawning of the Finte in the Elbe in the second half of May, and then obtained eggs with welldeveloped embryos, and also larvæ with large yolk-sacs. Towards the end of May he captured numerous larvæ of 8 to $9 \mathrm{~mm}$. in length, which retained a trace of the yolk, and on the 17th June larvæ of $9 \mathrm{~mm}$. to $1 \cdot 4 \mathrm{~cm}$. He obtained no more larvæ, but in August got the specimens above mentioned, which were taken in nets, and were already fully scaled and had the form of the adult. He concluded from this that the young larvæ hatched in the river migrate to the sea as soon as the yolk has been absorbed, only returning to the river in the following year, at the size mentioned. This conclusion is obviously erroneous. Supposing all the specimens to belong to the species Clupea finta, thoughit is not proved that they were not Olupea alosa, we have to consider what is the size of the former species when full grown. Day says it attains to 16 inches in length, so that it is somewhat larger than the herring. Meyer has shown that the spring herring spawned in April and May, have by the end of July for the most part completed their metamorphosis, and are then 4.5 to 5.5 $\mathrm{cm}$. long. What is there then to prevent the shad spawned in May from completing its metamorphosis by the middle of August, and reaching a length of $5 \cdot 4$ to $7 \cdot 8 \mathrm{~cm}$.? The herring, according to Meyer, is $8.4 \mathrm{~cm}$. long and upwards by the middle of November, and yet Ehrenbaum maintains that specimens of the twaite shad, a larger fish when full grown, which are 8.0 to $12.4 \mathrm{~cm}$. long in November, are eighteen months old. He compares his observations on the shad with Hoffmann's on the anchory, and concludes that the shad takes eighteen months to reach the same length that the anchovy reaches in seventeen, regardless of the fact that the adult anchovy is scarcely half the length, and much less than half the weight of the adult twaite shad.

NEW SERIES.-VOL, II, NO. III. 
The observations and conclusions of Metzger and Hoek, to which Ehrenbaum refers, are contained in a Report on the Ankerkuil and Staalboomen fishery of the Hollandsch Diep, and Haringvliet,* which names are applied to different portions of the broadest estuarine channel at the mouth of the Maas or Meuse. In the Report itself observations on the young of Clupea alosa and Clupea finta are recorded in separate tables.

The observations of young C. alosa are-

\begin{tabular}{|c|c|c|c|c|}
\hline Date. & & Number. & & Length. \\
\hline April 27,1887 & $\ldots$ & 15 & $\ldots$ & $10-11 \cdot 6 \mathrm{~cm}$ \\
\hline , 27,1887 & $\ldots$ & 25 & $\ldots$ & $9-12.5$ \\
\hline May 18,1887 & $\ldots$ & 9 & $\ldots$ & $8 \cdot 8-11 \cdot 4$, \\
\hline June 18, 1886 & $\ldots$ & 10 & $\ldots$ & $11.5-13.5$ \\
\hline „18, 1886 & $\ldots$ & 8 & $\ldots$ & $11 \cdot 0-12 \cdot 0$ \\
\hline , 21,1886 & $\ldots$ & 1 & $\ldots$ & $25 \cdot 5$ \\
\hline \# 22,1886 & $\ldots$ & 4 & $\ldots$ & $9 \cdot 6-13 \cdot 6$ \\
\hline July 28,1886 & $\ldots$ & 1 & $\ldots$ & $16 \cdot 0$, \\
\hline October 21,1886 & $\ldots$ & 8 & $\ldots$ & $7 \cdot 2-8 \cdot 0$, \\
\hline , $\quad 21,1886$ & $\ldots$ & 7 & $\ldots$ & $7 \cdot 5-9 \cdot 3$, \\
\hline 21,1886 & $\ldots$ & 20 & $\ldots$ & $9 \cdot 0-11 \cdot 3$, \\
\hline 21,1886 & $\ldots$ & 35 & $\ldots$ & $9 \cdot 0-14: 3$, \\
\hline $22-24,1886$ & $\ldots$ & $3-25$ & $\ldots$ & $5.8-8.7$, \\
\hline $23-24,1886$ & $\ldots$ & $5-9$ & $\ldots$ & $7 \cdot 2-10 \cdot 0$ \\
\hline
\end{tabular}

The figures in the table do not exactly agree with those mentioned in the text (p. 121), although they apparently refer to the same observations; the differences are not great, but sufficient to puzzle the reader. In the text it is mentioned that specimens of 3.5 to $3.8 \mathrm{~cm}$. in length were taken on $22 \mathrm{nd}$ and $23 \mathrm{rd}$ of July, 1886, and these are not included in the table at all. It is stated that the shad enters the river in April and May, that it is believed to spawn in the higher parts of the Rhine and its tributaries, but that it is not known whether some individuals may possibly spawn in the lower part of the river. The time of spawning is not absolutely ascertained; according to Kröyer and Nilsson the spawning takes place in June and July; according to Day between the beginning of May and the middle of June. It seems to me likely enough that the spawning may be continued from the end of April until July. Metzger and Hoek state that 60 and $70 \mathrm{~cm}$. is no uncommon length for the shad, that is 2 feet and upwards. In the Report proper, the authors conclude that the fish of 3.5 and $3.8 \mathrm{~cm}$. taken at the end of July were from the spawn shed the same year, and were therefore about two months old. Those taken in November under $6.0 \mathrm{~cm}$. long are also supposed to have been hatched in the

* Published separately and also as Supplementband II of the Tijdschrift der Nederlandsche Dierkundige Vereeniging. Leiden, 1888. 
previous spring. I find that the German version of the Report is not always an accurate rendering of the Dutch. As I understand the latter, it says (p. 120) that like most of those taken in October, November, April, and May, so also those taken in June, 1886, were derived from the spawning of the year preceding that in which they were taken; that is, they were a year old or more. But the question is raised whether the fish of $7 \cdot 2 \mathrm{~cm}$. taken in October were of the same age as those $14 \cdot 2 \mathrm{~cm}$. taken in the same month.

My own opinion is that the specimens taken in April, May, and June, except the one $25.5 \mathrm{~cm}$. long, were about a year old, having been hatched in the spring of the preceding year; but I cannot help thinking that these were all unusually small specimens, which had not reached the normal size of yearling shad. Hoek and Bottemane themselves estimate the age of specimens 25 to $31 \mathrm{~cm}$. in length, taken in May, June, and July at two years, and, according to this specimen, one year old ought to be about 17 to $20 \mathrm{~cm}$. in length. I consider that the specimens taken in October and November are all derived from the spawning of the spring of the same year, not, as the authors conclude, from the spawning of the preceding year.

The observations on Clupea finta in the same Report are tabulated as follows :

\begin{tabular}{|c|c|c|c|c|c|c|c|}
\hline April 27,1887 & ... & \multicolumn{2}{|c|}{93 specimens } & $\ldots$ & \multicolumn{3}{|c|}{$8.9-9.2 \mathrm{~cm}$. long. } \\
\hline May 18,1887 & ... & 4 & " & $\ldots$ & $7 \cdot 2-8 \cdot 4$ & , & ", \\
\hline June 18, 1886 & ... & 8 & $"$ & $\ldots$ & $7 \cdot 7-10 \cdot 0$ & , & , \\
\hline , 18,1886 & $\cdots$ & 1 & , & $\ldots$ & $8 \cdot 9$ & $"$ & " \\
\hline$\Rightarrow \quad 18,1886$ & ... & 3 & , & $\cdots$ & $9 \cdot 7$ & , & ", \\
\hline , 22,1886 & $\ldots$ & 6 & ", & $\ldots$ & $9 \cdot 1-11 \cdot 2$ & , & " \\
\hline$\Rightarrow \quad 22,1886$ & $\cdots$ & 13 & " & $\cdots$ & $10 \cdot 5-12 \cdot 0$ & , & " \\
\hline October 4, 1886 & $\ldots$ & 5 & $"$ & $\ldots$ & $9 \cdot 0-11 \cdot 5$ & , & ", \\
\hline , 21,1886 & $\cdots$ & 12 & , & $\ldots$ & $6.7-8.9$ & , & ” \\
\hline , 21,1886 & $\cdots$ & 3 & , & ... & $6 \cdot 3-8 \cdot 7$ & ", & $"$ \\
\hline , 21,1886 & $\ldots$ & 17 & , & ... & $9 \cdot 0-15 \cdot 0$ & , & " \\
\hline$\Rightarrow \quad 21,1886$ & $\ldots$ & 18 & , & $\ldots$ & $10 \cdot 0-12 \cdot 3$ & , & , \\
\hline , $22-24,1886$ & $\cdots$ & 27 & " & $\ldots$ & $5 \cdot 4-10 \cdot 0$ & " & " \\
\hline vember $23-24,1886$ & $\ldots$ & $3-8$ & " & ... & $5 \cdot 8-10 \cdot 4$ & " & " \\
\hline
\end{tabular}

The special discussion of these observations is given in the Report proper. My own interpretation is that all those in the first of the two parts into which I have divided the table are from the spawning of the previous year, while of those in the second part of the table the greater number are from the spawning of the preceding spring of the year in which they were captured. The largest of those taken in October, those over $12 \mathrm{~cm}$. in length, may very possibly be in their second year.

In an appendix to the report by Hoek, specially devoted to the fish larvæ and young fish observed, that zoologist gives reasons 
which incline him to modify the opinion expressed in the Report proper concerning the age of young fish about $4.5 \mathrm{~cm}$. long, which already had acquired the permanent form of the adult, and which were taken towards the end of July, 1886. The length of these fish is given in the body of the Report as 3.5 to $3.8 \mathrm{~cm}$. Hoek argues that if the shad (C. alosa) spawns, as Kröyer and Nilsson say, in June and July, these fish must be a year old, and mentions in support of the latter conclusion that the sea-herring takes seven to nine months before it undergoes its metamorphosis from the larval form to that of the adult. This latter fact is taken by Hoek from the results of Meyer and Heincke, published in the Reports of the Commission zur Untersuchung der deutschen Meere in Kiel. But it seems to me that, in the first place, Hoek has somewhat exaggerated the statements of Meyer and Heincke. It is true that the latter observers found that some herring larvæ hatched in autumn and winter did not attain to the perfect form until June and July; but the German investigators do not suggest that the eggs from which these larvæ came were shed in October, but later in November and December; and Meyer further points out that the water is then very cold, and that the eggs take many weeks to hatch, so that the larvæ taken in June are more probably four or five months old, reckoning from the time of hatching, than seven to nine months. Another important consideration overlooked by Hoek is that these larvæ of the autumn, or sea-herring, are 5 to $6 \mathrm{~cm}$. long before they have completed their metamorphosis, while the young shad to which Hoek refers had already attained to the perfect and permanent form at $4.5 \mathrm{~cm}$. What probability is there that the young of so large a fish as the shad when $4.5 \mathrm{~cm}$. long should be five to seven months older than the larva of a herring 5 to $6 \mathrm{~cm}$. long? Then again the shad is hatched in spring in warm water, why then should its growth be compared with that of the winter herring, whose eggs and larvæ are produced at the coldest time of the year, rather than with the growth of the spring herring? 
